\title{
All100 993114
}

NATL INST OF STANDARDS \& TECH R.I.C.

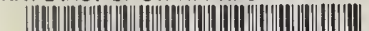

A11100993114

eyendecker, Edgar V/The Incldence of ab TA435 U58 V89.9976 C. 1 NBS-PUB-C 1976

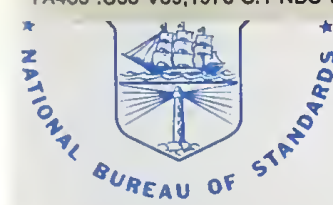

\section{NBS BUILDING SCIENCE SERIES 89}

\section{U.S. DEPARTMENT OF COMMERCE / National Bureau of Standards}

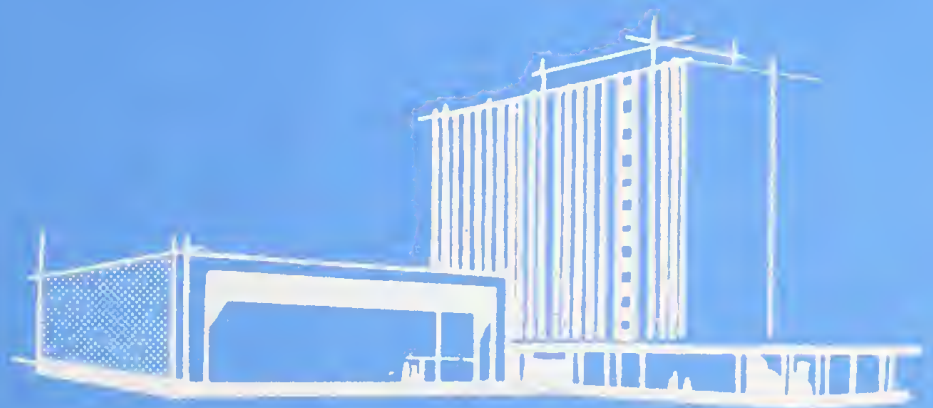

\section{The Incidence of Abnormal Loading in Residential Buildings}

TA

435

.458

No.89

1976

c. 2 


\section{The Building Science Series}

The Building Science Series disseminates technical information developed at the National Bureau of Standards on building materials, components, systems, and whole structures. The Series presents research results, test methods, and performance criteria related to the structural and environmental functions and the durability and safety characteristics of building elements and systems.

These publications, similar in style and content to the NBS Building Materials and Structures Reports (1938-59), are directed toward the manufacturing, design, construction, and research segments of the building industry, standards organizations, and officials responsible for building codes.

The material for this Series originates principally in the Center for Building Technology of the NBS Institute for Applied Technology. The publications are divided into three general groups: Building Systems and Processes; Health, Safety and Comfort; and Structures and Materials. For further information regarding these publications please contact the Program Planning and Liaison Unit, Center for Building Technology, Institute for Applied Technology, National Bureau of Standards, Washington, D.C. 20234. 


\section{The Incidence of Abnormal Loading in Residential Buildings}

\section{nBS}

Edgar V. Leyendecker

Center for Building Technology

Institute for Applied Technology

National Bureau of Standards

Washington, D.C. 20234

Eric F. P. Burnett

University of Waterloo

Ontario, Canada

Sponsored by the

Division of Energy, Building Technology and Standards

Office of Policy Development and Research

Department of Housing and Urban Development

Washington, D.C. 20410

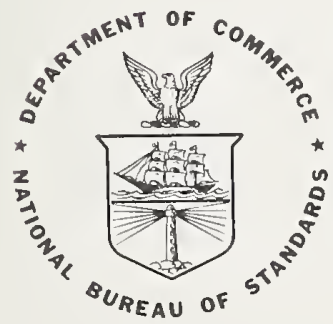

U.S. DEPARTMENT OF COMMERCE, Elliot L. Richardson, Secretary

Edward O. Vetter, Under Secrefary

Dr. Betsy Ancker-Johnson, Assistant Secretary for Science and Technology

NATIONAL BUREAU OF STANDARDS, Ernest Ambler, Acting Director

Issued December 1976 


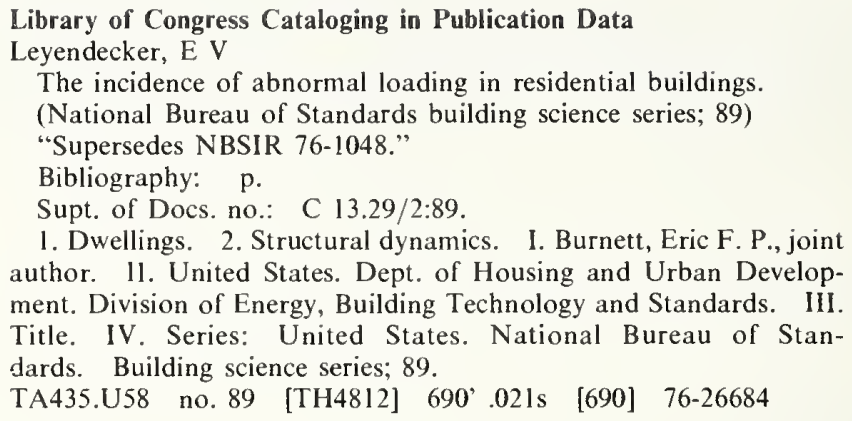
author. 11. United States. Dept. of Housing and Urban Development. Division of Energy, Building Technology and Standards. III. Title. IV. Series: United States. National Bureau of Standards. Building science series; 89.

TA435.U58 no. 89 [TH4812] 690'.021s [690] 76-26684

\section{National Bureau of Standards Building Science Series 89}

Nat. Bur. Stand. (U.S.), Bldg. Sci. Ser. 89, 31 pages (Dec. 1976)

CODEN: BSSNBV

Supersedes NBSIR 76-1048

\section{U.S. GOVERNMENT PRINTING OFFICE WASHINGTON: 1976}

For sale by the Superintendent of Documents, U.S. Government Printing Office, Washington, D.C. 20402

(Order by SD Catalog No. C13.29/2:89). Stock No. 003-003-01706-0. Price 75 cents.

(Add 25 percent additional for other than U.S. mailing).

There is a minimum charge of $\$ 1.00$ for each mail order. 


\section{Contents}

SI Conversion Units

1. Introduction

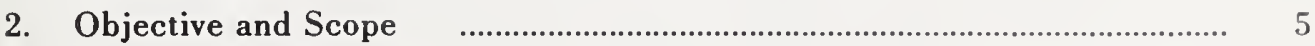

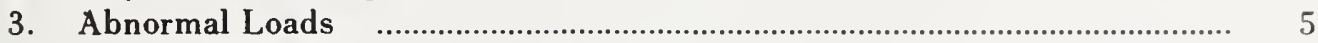

3.1 General ................................................................................... 5

3.2 Gas-Related Explosions $\quad$...................................................................... 5

3.3 Bomb Explosions $\quad$.............................................................................. 8

3.4 Motor Vehicle Collision with Buildings $\quad$...................................... 12

3.5 Sonic Boom …...................................................................................... $\quad 12$

3.6 Aircraft Collision with Buildings $\quad$................................................ 13

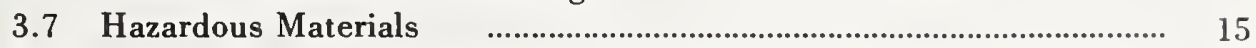

4. Evaluation of Data …........................................................................... 15

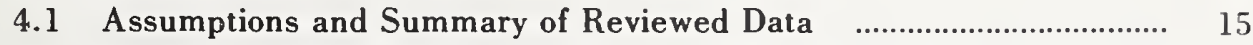

4.2 Effect of Building Size $\quad$....................................................................... 17

4.3 Comparison with Other Data …....................................................... 21

4.4 Load Data ........................................................................................ 22

5. Conclusions and Concluding Remarks …................................................. 22

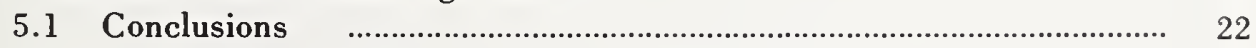

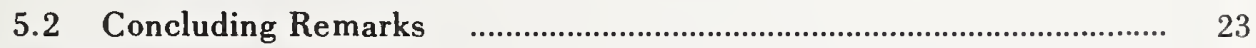

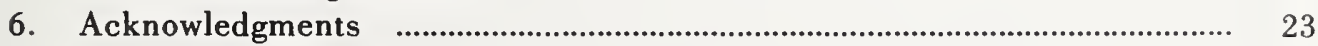

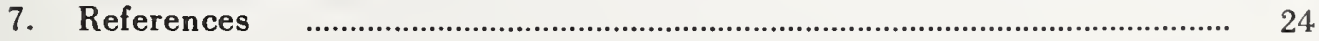




\section{SI Conversion Units}

In view of present accepted practice in this technological area, U.S. customary units of measurement have been used throughout this report. It should be noted that the U.S. is a signatory to the General Conference on Weights and Measures which gave official status to the metric SI system of units in 1960. Readers interested in making use of the coherent system of SI units will find conversion factors in ASTM Standard Metric Practice Guide, ASTM Designation E 380-74 (available from American Society for Testing and Materials, 1916 Race Street, Philadelphia, Pennsylvania 19103). Conversion factors for units used in this paper are:

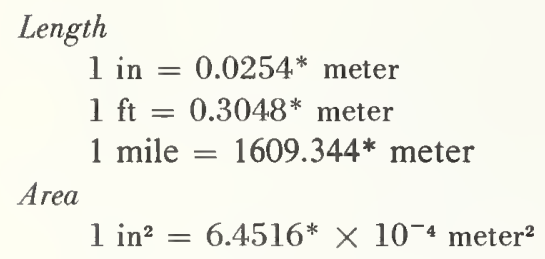

$$
\begin{aligned}
& \text { Force } \\
& 1 \mathrm{lb}(\mathrm{lbf})=4.448 \text { newton } \\
& \text { Pressure } \\
& \qquad 1 \mathrm{psi}=6895 \mathrm{~N} / \mathrm{m}^{2}
\end{aligned}
$$




\title{
The Incidence of Abnormal Loading in Residential Buildings
}

\author{
Edgar V. Leyendecker* and Eric F. P. Burnett**
}

\begin{abstract}
The findings of an analysis of available U.S. statistics concerning the incidence of abnormal loading events in residential buildings are presented. The study evaluates natural gas explosions, bomb explosions, motor vehicle collision, sonic boom, aircraft collision, and explosion of hazardous materials.

It is concluded that the gas-related explosion, bomb explosion, and vehicular collision are of significance in building design for progressive collapse. Of these, the natural gas explosion is the most significant in terms of incidence. The gas explosion causing severe damage occurs with an annual frequency of 1.6 per million dwelling units and approaches a probability of $1 \times 10^{-3}$ per apartment building per year.
\end{abstract}

Key words: Bombs; building codes; design criteria; explosions; gas; hazardous materials; loads; progressive collapse: sonic boom; vehicular collision.

\section{Introduction}

There has been international concern that buildings, particularly multistory buildings, may be susceptible to a progressive "house of cards" type of failure. This concern was intensified with the Ronan Point apartment collapse in London, England, in 1968 (fig. 1). In this 22-story building of precast concrete panel construction, collapse was precipitated by a gas explosion in the kitchen of an apartment on the 18th floor. The explosion blew out an exterior wall panel; the loss of support provided by the panel resulted in a chain reaction of collapse to the roof. The collapse also progressed almost to the ground as debris from above fell on successive floors below [23].1 This type of chain reaction, or propagation of failure, following damage to a relatively small portion of a structure, has been termed "progressive collapse."

Allen and Schriever [4] conducted a survey to determine the frequency of occurrence of progressive type of collapses. They used two news sources-the Engineering News Record (ENR) from 1968 to 1972 and newspaper clippings from Canadian newspapers from 1962 to 1972. The results of the Allen and Schriever survey are

-Dr. Leyendecker is a Structural Research Engineer at the National Bureau of Standards.

- Dr. Burnetl is an Associate Professor of Civil Engineering at the University of Waterloo, Ontario, Canada, and was a Guest Worker at the National Bureau of Standards, October 1971 to April 1972.

1 Figures in brackets indicate literature references. shown in figure 2. Based upon the ENR data, an estimate of $51 / 2$ progressive collapses per year was obtained. This is about 20 percent of the total of 110 collapses recorded by ENR during the 4-year survey period. The newspaper survey over a 10-year period resulted in a slightly larger annual estimate of progressive collapses, 7 1/2 per year, which constituted a smaller percentage, about 15 percent, of the total number of collapses. These are most likely lower bound estimates since it is considered unlikely that the data sources included all collapses.

The initial failure which leads to a progressive collapse may be caused by an abnormal loading, that is, a condition of loading with a small probability of occurrence which a designer does not consider in the normal analysis and design of a particular structure. The gas explosion at Ronan Point is an example of such a loading. Using the previously described data sources, Allen and Schriever also compiled the occurrence of abnormal loads (fig. 3 ) causing heavy damage. The results of their survey fell roughly into three categories; explosions, impact, and foundation mishaps. They also pointed out that both fire and abnormally low strengths due to faulty design or workmanship could be the initiating cause of a progressive collapse.

In 1971 Ligtenberg [24] published a paper on structural safety and fire which included data on sources of building damage in the Netherlands (fig. 4). The sources of damage included explosions, 


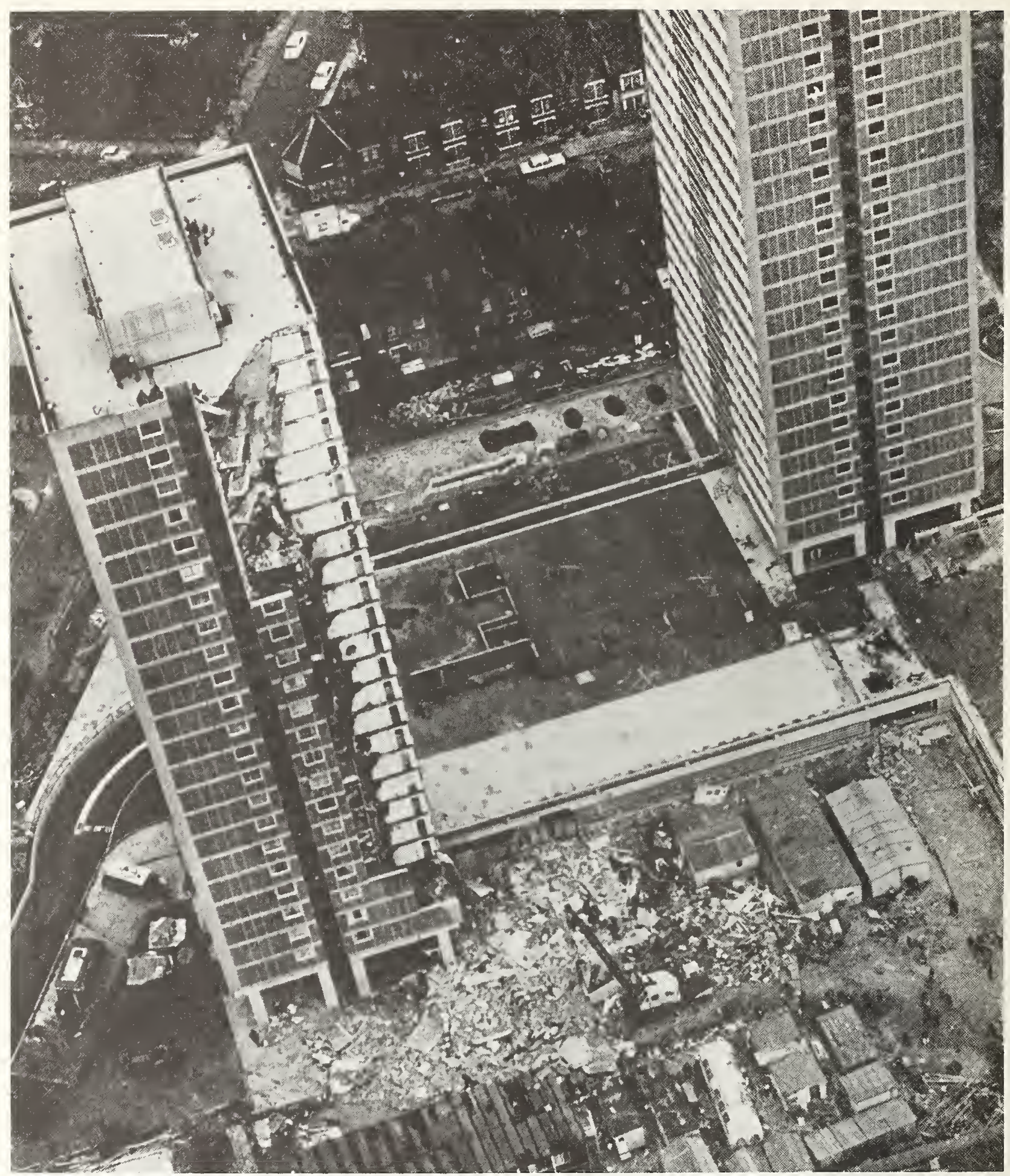

Figure 1. Ronan Point Apartment Building after the collapse, with a second identical building in the background. (Courtesy of London Express News and Feature Services). 


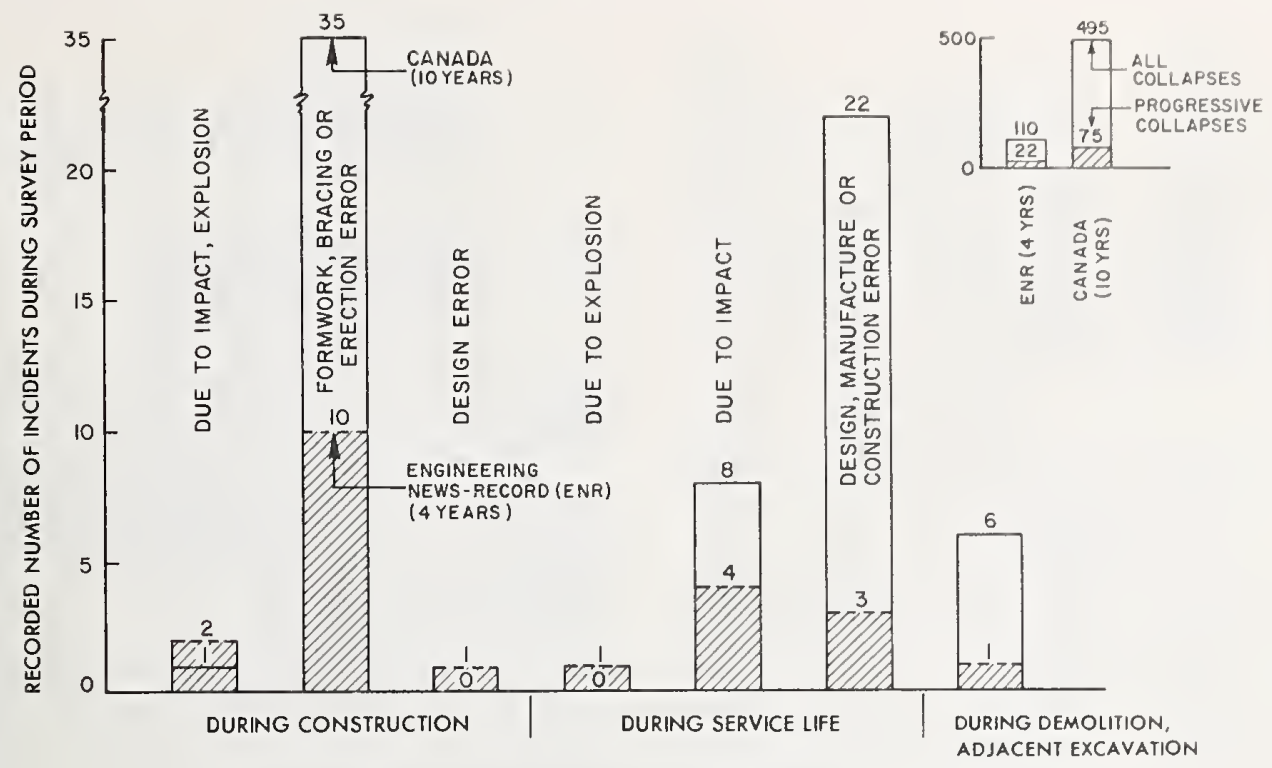

Ficure, 2. News incidents recording progressive collapse [4].

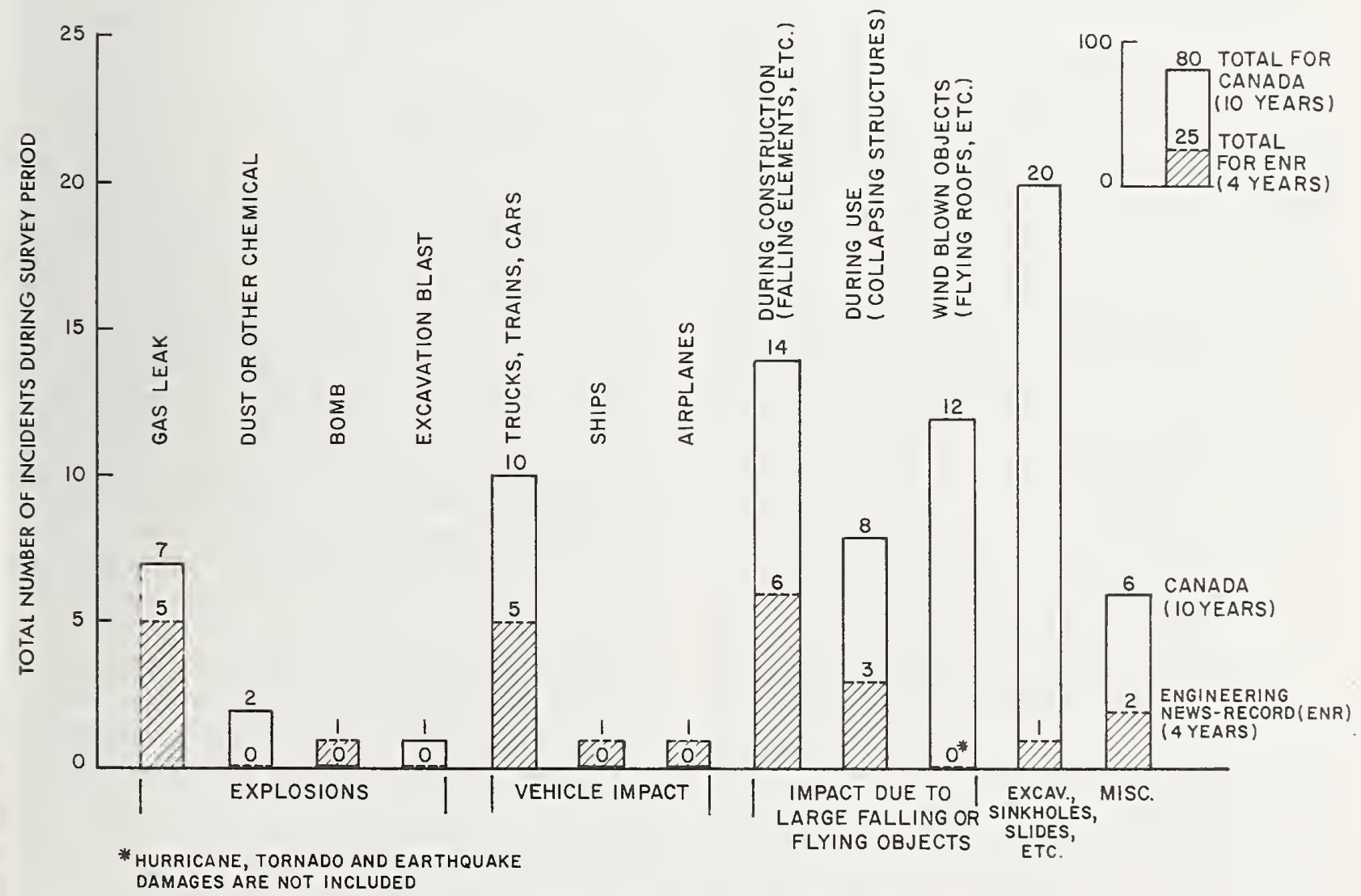

Figure 3. News incidents of abnormal loads causing heavy damage [4]. 


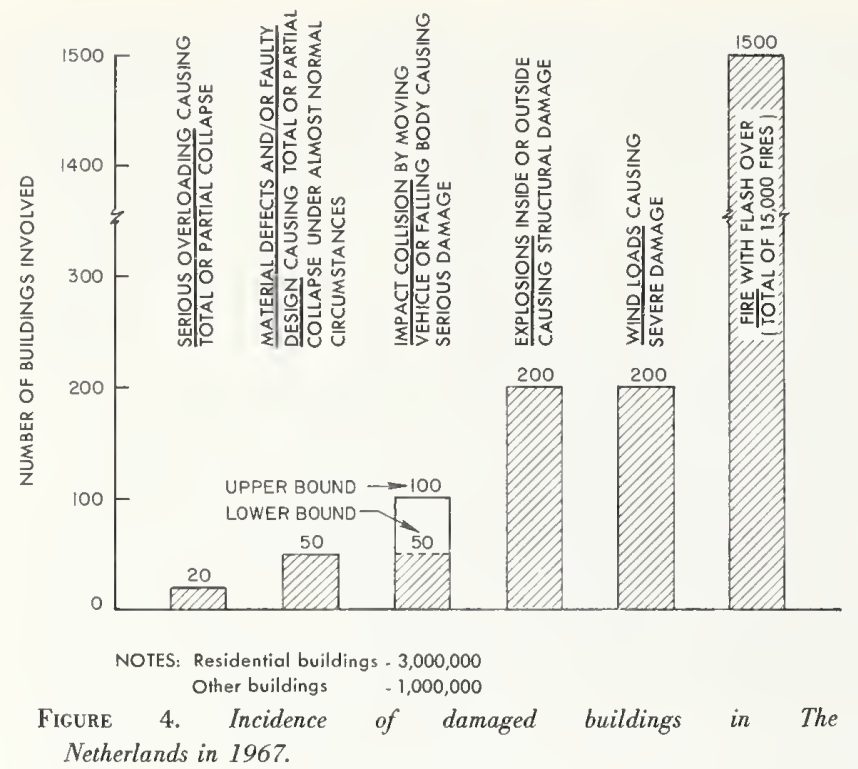

impact, wind loads, overloading, material defects/faulty design, and fire. These damage sources are similar to those described by Allen and Schriever.

Ligtenberg described several of these loadings as "extreme situations" (i.e., fire, collision, and explosion). He observed that the action (e.g., the direction of load application) of these "extreme situations" on a structure may be completely different from the "normal situation" used for design purposes. Hence, attempts to modify customary design methods by merely increasing the loads encountered in the "normal situation" by a "factor of safety" in an effort to account for the "extreme situation" are not realistic and may lead to erroneous results.

Somes [32] has attempted to classify the various abnormal loadings as follows:

A. Violent Change in Air Pressure

Sabotage bombings

Service system explosions

Other explosions within the building

Explosions external to the building

B. Accidental Impact

Highway vehicles

Construction equipment

Aircraft
C. Faulty Practice

Design error

Construction error

Misuse or abuse by the occupant

D. Foundation Failure

Unforeseen settlement

Foundation wall failure

Burnett [13] has developed a more extensive classification system.

It is likely that the greatest number of abnormal loadings occur during wartime. McGuire [25] has summarized one British report on wartime experiences as follows:

In reviewing British experience in World War II, Baker, Williams, and Lax observed: "One of the outstanding facts . . . of the air attacks on this country was the very high resistance of framed buildings to the effects of high-explosive bombs." [7]

For multistory steel framed buildings they found that, "in general the extent to which the presence of the steel framework limits the destructive effect of the bomb on the building as $a$ whole is very remarkable, when compared with the typical effects in multistory load-bearing wall buildings. The virtual absence of any progressive coliapse enables the floors and walls which are in quite close proximity to the bomb to remain effective as screens for those portions of the building which are more remote, with the result that the area of bad damage to the structure is very small."

In multistory concrete framed buildings the conclusion was the same: "Obviously nothing can be done to limit the zone of primary damage, but fortunately it is so small that the danger of resultant collapse is not serious. The continuity of most reinforced concrete framing is such that the structure will bridge over the demolished portion. If the only damage to the structure were that due to the primary effect of the explosion, it is fairly safe to say that no serious collapse would ever result"

Findings such as these induced somewhat of a state of euphoria in structural design. There seemed, until recently, to be a general feeling that if one followed established practice and codes the resulting building would have inherent ability to transmit forces around any area damaged by any abnormal incident. 
This feeling persisted even though some of the practices responsible for the good record were changing. Multistory structural forms were devised which do not have the redundancy or ductility of conventional frames. Modern in-filling may not have the incidental structural resistance provided by most of the older partitions and non. load bearing walls. Many of these developments have been used successfully and economically in compliance with established building codes.

The difference between some of the newer structures and the traditional ones was brought out in a tragic way in the Ronan Point collapse.

In view of the changing practices mentioned by McGuire [25] and the differences between extreme loads (e.g., abnormal loads) and normal loads pointed out by Ligtenberg, [24] it is considered desirable to reassess abnormal loadings to determine whether or not they can continue to be neglected in design. Accordingly, the Department of Housing and Urban Development requested the National Bureau of Standards to prepare a study of the significance of such incidents on residential buildings with regard to progressive collapse.

\section{Objective and Scope}

The purpose of this report is to discuss sources of abnormal loading and to estimate the risk of such loading in residential building design. The chief criterion for selection of the loadings studied was plausibility. In this regard the data provided by Ligtenberg [24], Allen and Schriever [4], and the various classifications by Somes [32] and Burnett [13] were helpful in selecting the abnormal loadings described herein.

As has been indicated, these abnormal loadings occur rarely. Hence they are examined for their possible effect on structural integrity rather than their effect on serviceability.

Only loadings on completed buildings are considered. Although very important, loadings which might result as a consequence of faulty practice or during the construction phase are considered beyond the scope of this report. Fire is also excluded since fire protection is required in current codes and is thus considered a normal design requirement.

The following are the loadings discussed in this report:
- Gas-Related Explosions

- Bomb Explosions

- Motor Vehicle Collision with Buildings

- Sonic Boom

- Aircraft Collision with Buildings

- Explosion of Hazardous Materials

\section{Abnormal Loads}

\subsection{General}

The following sections contain information from documents which have been prepared as reference material for this report. These background documents are referenced in the section titles. The census data [11,12] used in determining annual frequencies are contained in table 1.

\subsection{Gas-Related Explosions [17]}

The explosions considered in this section are limited to incidents involving piped-gas distribution systems. Explosions relating either to gas transmission or to gathering systems or bottled or stored gas are not included. The most common forms of gas distributed by pipeline are natural gas, manufactured gas, liquified petroleum gas (propane and butane), and mixed gas (usually manufactured plus natural or liquified petroleum gas). In terms of residential consumption in 1970 , 98.5 percent of all gas utility customers used natural gas [22] and, for all practical purposes, the data for natural gas may be considered to be representative of the industry.

Gas-related explosions result from the leakage, accumulation, and ignition of gas. The Office of Pipeline Safety (OPS) [17] of the U.S. Department of Transportation reported that between 1970 and 1972 leaks occurred at the average rate of about one leak for every mile of gas distribution system (fig. 5). Considering the number of miles of gas distribution pipeline, the incidence of leaks, the proportion of the population served directly with gas, and the fact that a gas-related explosion can occur in buildings that are not directly supplied with gas, it is evident that gas-related explosions could pose structural problems for buildings in built-up or urban areas wherever a gas-distribution system exists. It should be noted that a dwelling unit may be affected not only by an explosion 
TABLE 1. Housing data for 1960 and 1970

Units per Building

Owner Occupied

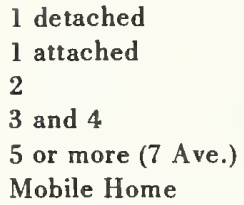

28.436

1.526

1.443

0.456

0.258

0.677

32.797

Renter Occupied

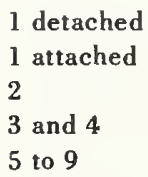

10 to 19

20 to 49

50 or more

Mobile Home

Vacant for Rent

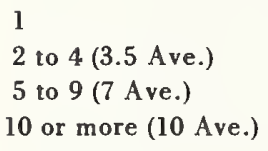

\begin{tabular}{lrr} 
& \multicolumn{1}{c}{} & \\
& 54.426 & 1.666 \\
Summed Total & 54.40 & 65.108 \\
$\begin{array}{l}\text { Total Number of Housing } \\
\text { Units in U.S. }\end{array}$ & 58.326 & 67.699
\end{tabular}

- Taken from 1960 and 1970 Census of Housing, Detailed Housing

Characteristics, United States Summary, Tables 5 and 22 respectively [11,12].

0.794

3.402

2.816

2.284

2.219

1.873

2.115

0.321

23.560

$0.603 \quad 0.571$

$0.378 \quad 0.407$

$0.154 \quad 0.194$

$0.291 \quad 0.494$

.666

108

7.699
1960 Housing 1970 Housing Units $\left(\times 10^{6}\right) * \quad$ Units $\left(\times 10^{6}\right)^{*}$

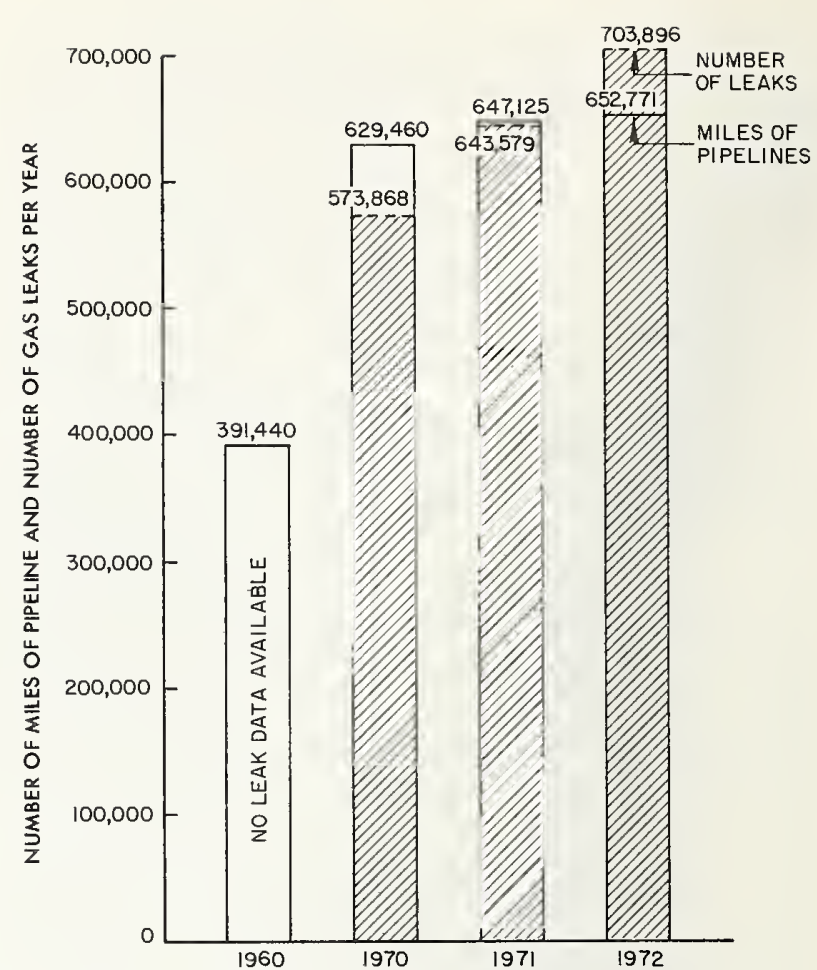

FigURE 5. Miles of pipeline and number of leaks.

.




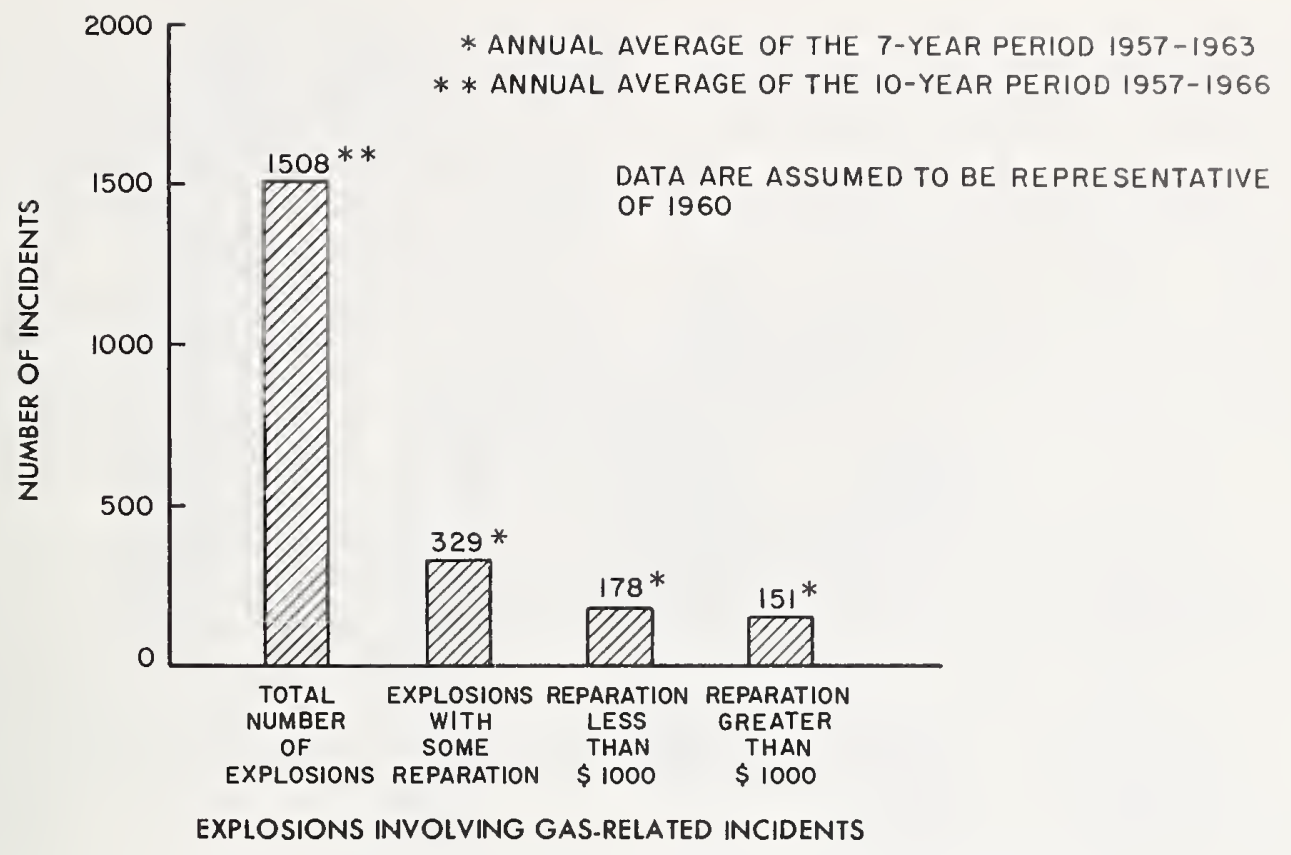

Figure 6. American Gas Association data on gas-related explosions.

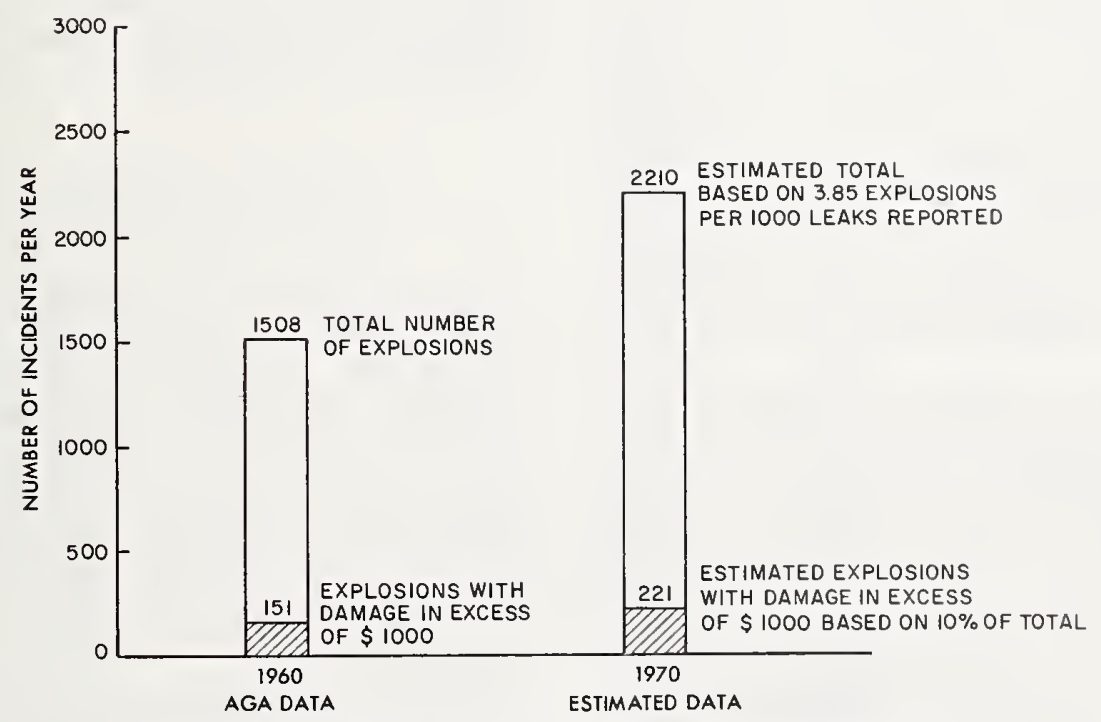

Figure 7. Number of gas -related explosions during 1960 and 1970. 
Explosion data from the OPS are shown in figure 8 . It is immediately apparent that the total number of explosive incidents reported by the OPS is an order of magnitude lower than the total number of explosive incidents reported by the AGA. Under the terms of the 1968 Natural Gas Pipeline Safety Act, all incidents of any consequence, that occur within gas-transportation systems, must be reported to the OPS by the gas company involved. However, the Act defines gas distribution systems as extending up to and including but not downstream (on the customer's side) of the meter. Accordingly, gas-related incidents caused by leaks that occur downstream of the customer's meter are not necessarily reported to the OPS. However, the AGA [5] reports that about 70 percent of all gas-related incidents and about 26 percent of all incidents involving payment arise from problems originating downstream of the customer's meter. This system of reporting (see ref. [17] for a further discussion of the reporting requirements) may also account for some of the variations between the AGA and OPS data shown in figures 7 and 8 respectively. Because of the different reporting systems, the OPS figures are considered by the authors as lower bound data for the frequency of gas-related explosions. The AGA figures are considered more representative than OPS figures for the total frequency of explosive incidents and the total incidence of explosions causing damage in excess of $\$ 1000$. However, the OPS data (fig. 8) do to a limited extent, identify the number of explosions involving residential buildings and which of these involved damage in excess of $\$ 1000$ and $\$ 10,000$. It should be pointed out that in some cases data were not available in terms of dollars of damage, in these cases the authors estimated an amount of damage.

The data for residential buildings are summarized in figure 9. Except for the 1508 and 151 reported explosions in 1960, the data in this figure are estimates. The number of incidents involving residential buildings was obtained by multiplying the total number of AGA reported incidents by the ratio of the OPS-reported incidents involving residential buildings to the OPS-reported total number of incidents. The number of residential buildings in the two damage categories was obtained by multiplying the AGA. reported incidents causing damage over $\$ 1000$ by the ratio of the OPS-reported incidents in the appropriate damage category to the OPS-reported incidents causing damage over $\$ 1000$. The estimates obtained by this procedure are thought to be reasonable ones for obtaining "order of magnitude" probabilities for gas-related explosions involving residential units.

Assuming each incident to involve only one residential unit and using a 1970 total of $67,700,000$ residential units (see table 1 ), the data in figure 9 may be used to obtain the following annual frequencies of occurrence:

\section{(1) 18 gas-related explosions per million dwelling units \\ (2) 2.5 gas-related explosions per million dwelling units causing damage in excess of $\$ 1000$ \\ (3) 1.6 gas-related explosions per million dwelling units causing damage in excess of $\$ 10,000$}

The $\$ 10,000$ structural damage level is thought to be reasonably indicative of explosions resulting in severe damage. Based upon this assumption, it can be estimated that about two severe gas explosions occur per week in the United States.

It should be noted that these statistics are independent of the number of the dwelling units in a building. Hence, the more units there are in a building serviced with gas the greater is the probability of a gas-related explosion occurring somewhere in the building.

\subsection{Bomb Explosions [16]}

The strategically-placed explosive bomb is judged to be the most potentially hazardous type of abnormal loading on a building. The determined, knowledgeable saboteur could cause extensive damage to a structure with little chance of being deterred. Fortunately this type of severe bombing incident is apparently rare in the United States at this time. Bombings do, however, occur in the United States and these are examined in this section.

A record of bombing activity within the United States has been maintained since mid-1970 following the establishment of the National Bomb Data Center (NBDC) $[9,10,26,27,28]$. During the period July 1970 through February 1972, the International Association of Chiefs of Police 


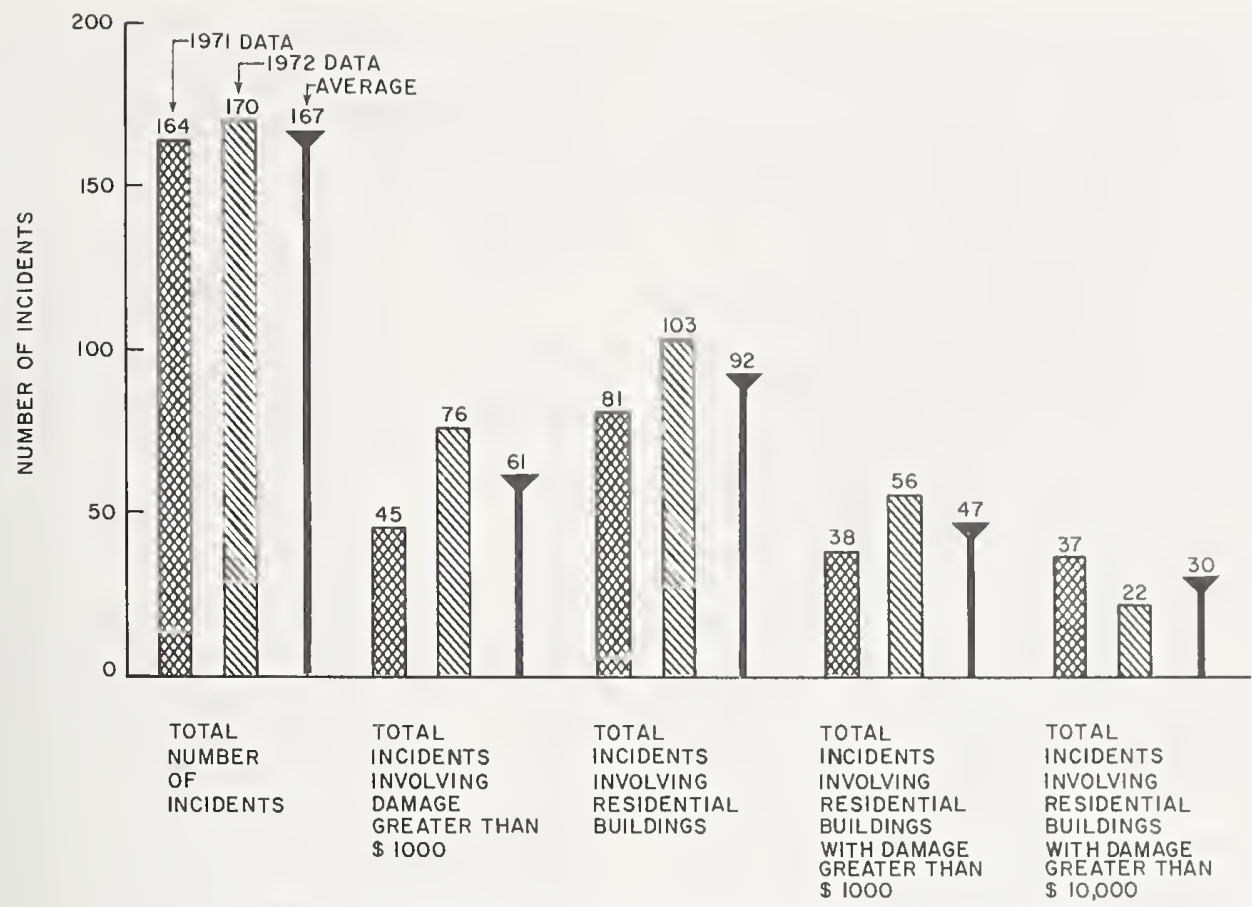

Ficure. 8. Office of Pipeline Safety data on gas-related explosions.

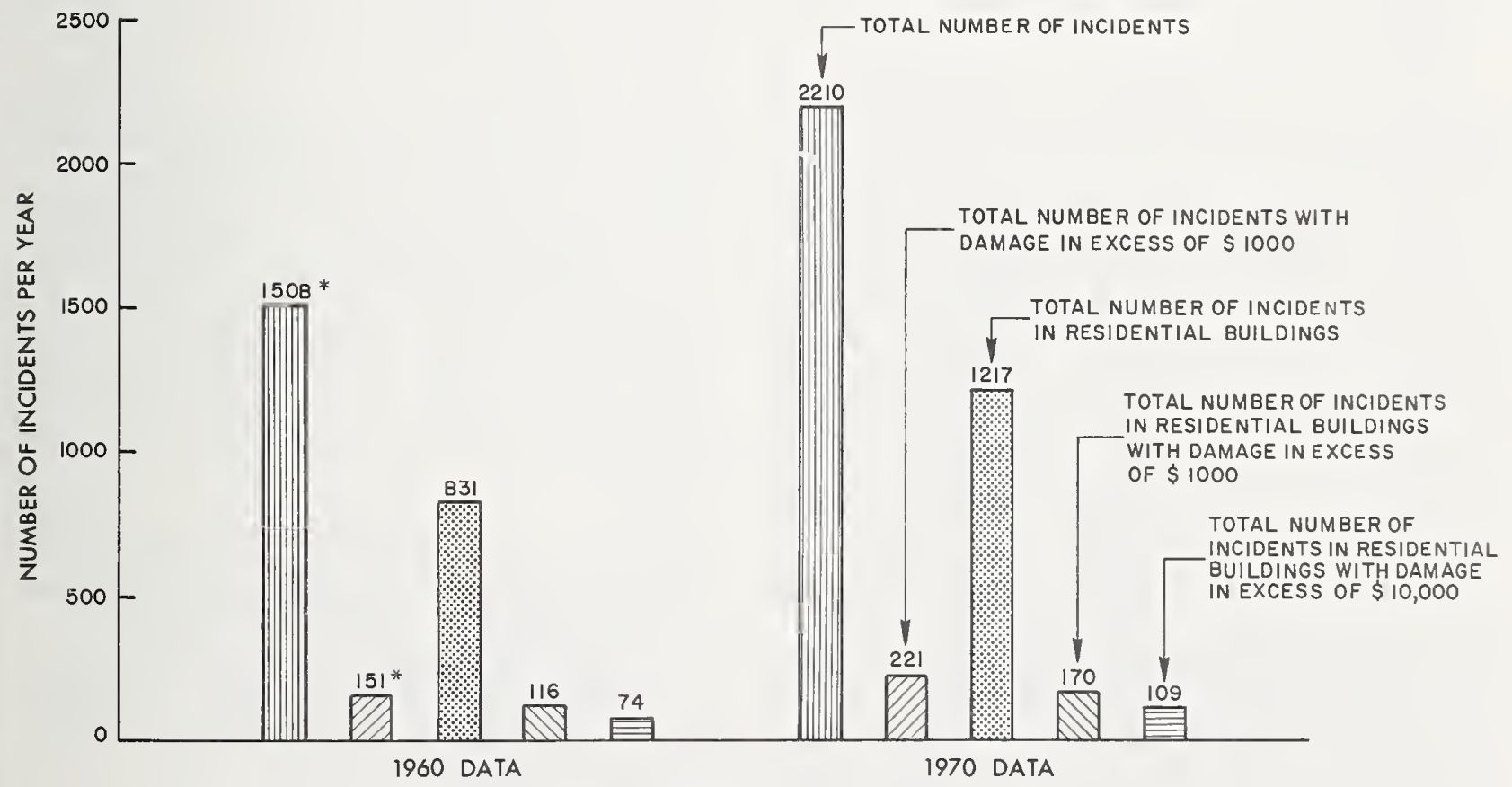

* actual data, other numbers are estimates

FIGURE 9. Estimated frequency of gas-related explosions in residential buildings. 
(IACP) operated the NBDC under the auspices of the U.S. Department of Justice. Subsequent to that time, the functions of the Center have been transferred to the Federal Bureau of Investigation (FBI). In addition, the California Department of Justice maintains records for that State [8].

Both IACP and FBI data for July 1970 through June 1974 are shown in figure $10[9,10,26,27,28]$. The total bombing activity is shown in figure 10(a) and residential bombing activity is shown in figure 10(b) for both explosive and incendiary bombing. The IACP data are most readily available for the entire 18-month period, July 1970 through December 1971, without a complete breakdown between 1970 and 1971. FBI data are available on an annual basis as shown. The IACP data may also be broken down as shown for total bombing activity, which is useful to observe trends. Based on the data shown, it appears that bombing activity decreased in 1974; although not to the 1970 level. The years 1971 and 1972 might have been influenced by the Vietnam conflict and the Presidential election. However, over this 30 -month period only 2.6 percent of all incidents were attributed to antiwar motives. About 22 percent of the incidents were considered politically related but the bulk of these were attributed to motives not necessarily peculiar to the years 1970, 1971, and 1972. Moreover, the majority of politicallyrelated incidents involved incendiary rather than explosive devices.

There were an average of 1929 explosive and incendiary bombing incidents during the reporting period (fig. 10a) with an average of 492 of these involving residential units (fig. 10b). The majority of these incidents involved incendiary bombs; however, this report considers only explosive bombings in which detonations actually occurred. It is important to point out that between 80 and 90 percent of the bomb attacks on residences were attributed to either personal animosity or malicious destruction. These motives are thought to be independent of whether a residence is a singlefamily dwelling or in a high-rise building.

The FBI data provide no information on damage levels to individual residences as a result of a bombing incident. On the other hand, the IACP data provide brief descriptions of most of the reported incidents. These descriptions may include dollar estimates of damage or descriptions such as minor damage or building destroyed. As a consequence, the IACP data are used in this report to determine the significance of bomb incidents.

The explosions were categorized in the following manner:

Moderate:

Windows blown out, doors blown off hinges, and partitions damaged and/or a damage estimate of less than $\$ 1000$.

Intermediate: Fairly extensive structural damage, such as walls blown down; and/or a damage estimate between $\$ 1000$ and $\$ 10,000$.

Severe: Extensive structural damage or dwelling unit destroyed; and/or a damage above $\$ 10,000$ and/or a death (a death was used only if no other data were available).

Both damage descriptions and dollars of damage were rarely available, thus the above descriptions involved some arbitrary judgment on the part of the authors.

The results of the examination of the IACP case records are shown in figure 11 (a) $[9,10,26,27,28]$ for the 18-month period July 1970 through December 1971. Some 83 of the 134 reported incidents caused moderate, intermediate, or severe damage. Each of the three damage categories constituted the percent of the total number of incidents as shown.

It is assumed that the percent of the total number of incidents for each damage category is valid for the average of the entire data period July 1970 through June 1974. Based on this assumption, the estimated annual data shown in figure $11(\mathrm{~b})$ were obtained. Only 8 incidents fell into the intermediate damage category while 15 were estimated in the severe damage category.

Using a 1970 total of $67,700,000$ residential units, the following frequencies of occurrence are obtained:

(1) 2.1 explosions per million residential units

(2) 0.92 explosions per million residential units causing causing moderate damage

(3) 0.12 explosions per million residential units causing intermediate damage (more than $\$ 1000$ but less than $\$ 10,000$ )

(4) 0.22 explosions per million residential units causing severe damage (more than $\$ 10,000$ ). 


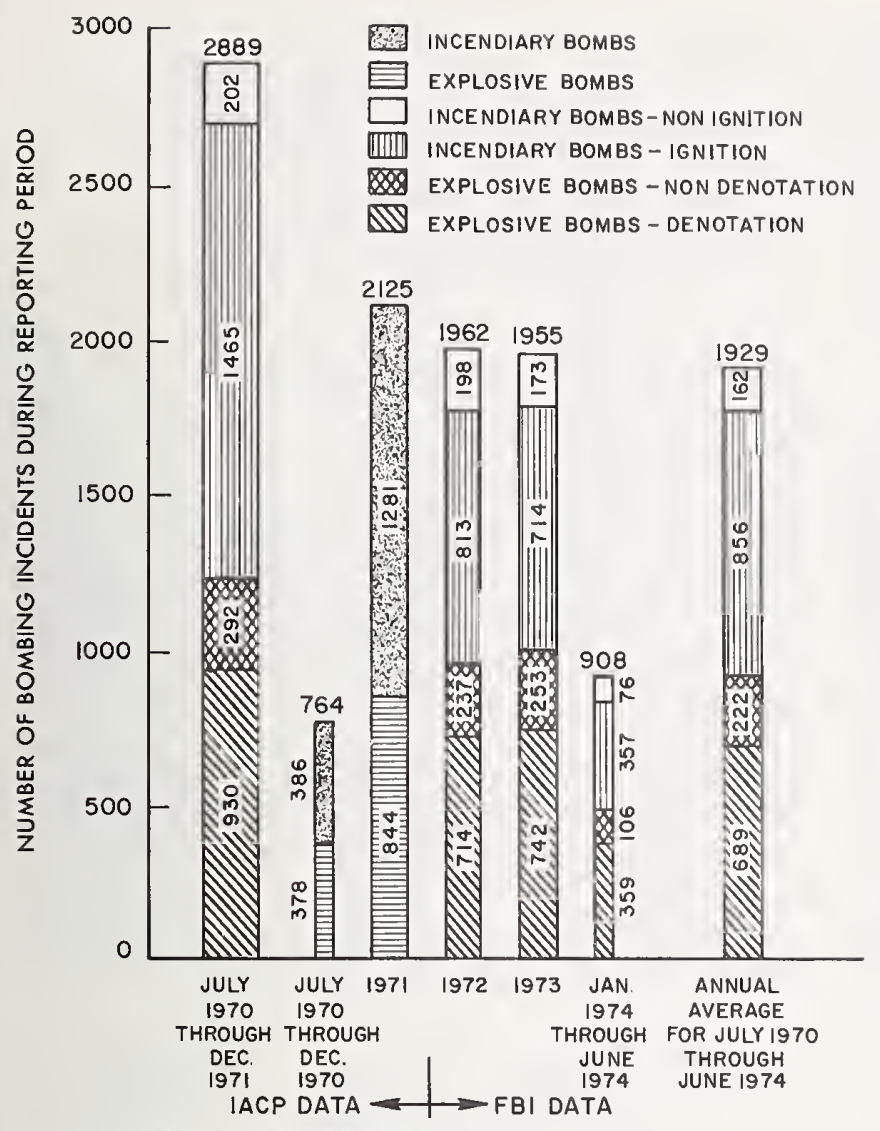

(a) TOTAL BOMBING ACTIVITY

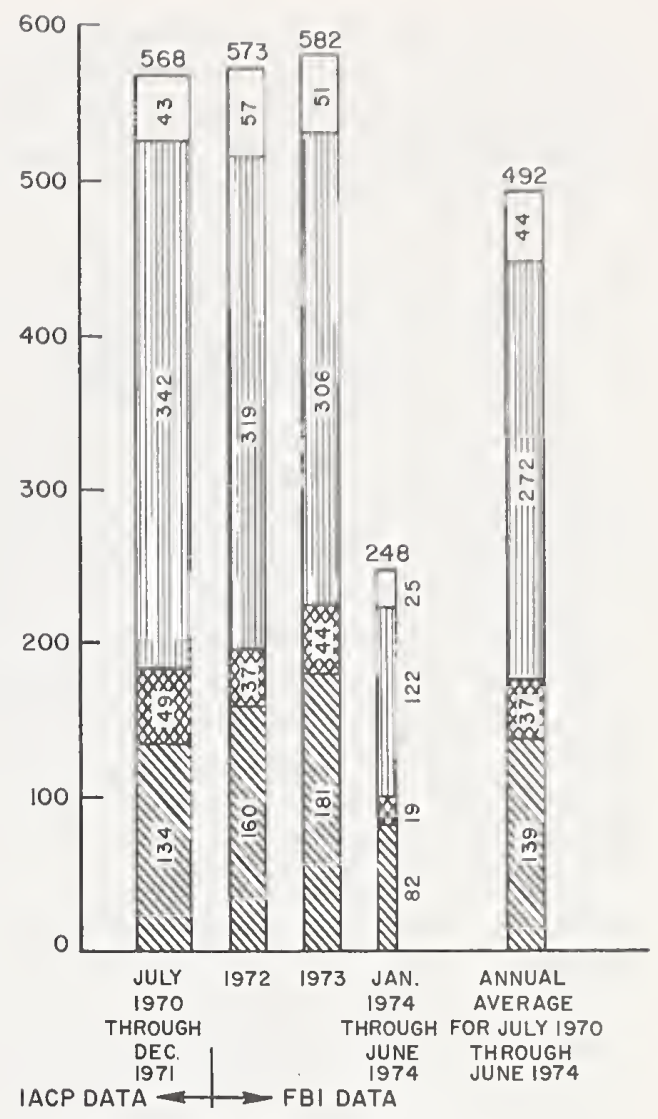

(b) RESIDENTIAL, BOMBING ACTIVITY

Ficuke: 10. Bombing activity in the United States $[9,10,26-28]$.

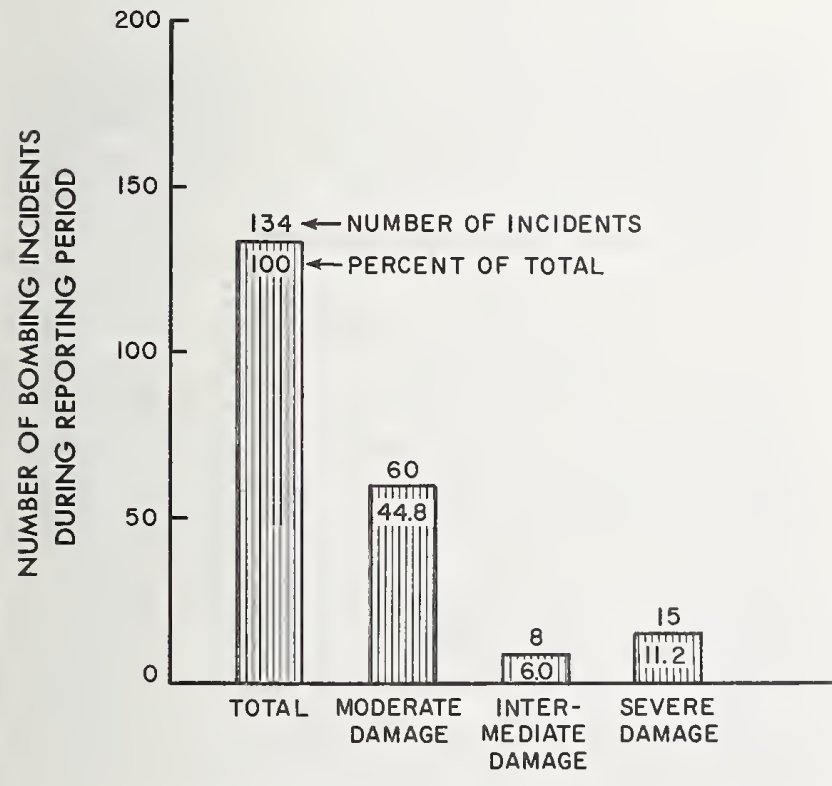

(a) IACP DATA FOR JULY 1970 THROUGH DECEMBER 1971

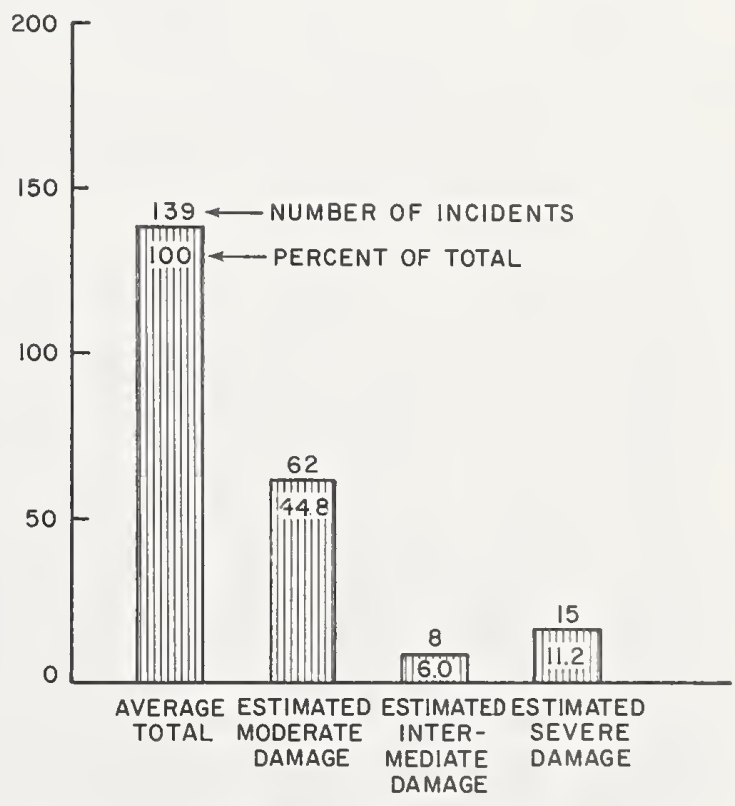

(b) ESTIMATED ANNUAL DATA

Figilnt 11. Residential bombing activity in the United States [9, 10, 26-28]. 
As in the case of gas explosions, these statistics on bombing incidents are independent of the number of $d$ welling units in a building. Thus the probability of an explosion occurring in a building increases with its size.

\subsection{Motor Vehicle Collision with Buildings [20]}

Some 16 million motor vehicle accidents of all types occurred in the United States during 1970 [2]. Although the various states collect a copious amount of records concerning these accidents, only a few states identify vehicle collision with a building as a particular category of data. Possibly because of this, there are no national statistics on vehicular collision with buildings. Fribush et al. [20], using data from two states, have attempted to estimate such data.

There are two classes of motor vehicle-building collision; namely (a) those involving a vehicle operating within its normal domain, e.g., an automobile colliding with a column in a parking garage, and (b) those collisions that occur as a consequence of the vehicle leaving its normal operating domain. Only the last class of accidents is considered in this report.

Fribush used two approaches to obtain estimates for the number of motor vehicle-building collisions. A crude proportionality model was used to project the accident records of the two data states based on both population and motor vehicle registration. This approach resulted in an estimate of about. 20,000 vehicular collisions with buildings during 1970. An alternate approach, based on regression analysis, resulted in an estimate of 40,500 collisions distributed between urban and rural areas as shown in figure 12. The estimates obtained from this second approach are used in this report since the regression analysis model considered more variables than the proportionality model.

No statistics were available which indicated the type of building struck or the extent of damage caused. However, data were available on the estimated dollars of damage for about one-half of the collisions in the two sample states. Based on these estimates, the data shown in figure 12 were obtained. About 5800 of the collisions are estimated to have caused non-auto property

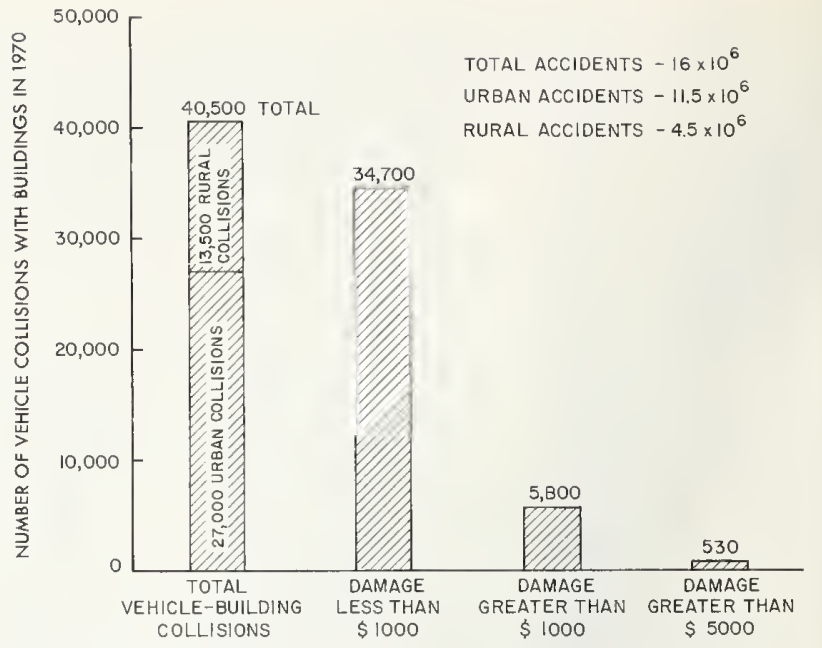

FIGURE 12. Estimated frequency of motor vehicle collision with buildings in 1970 .

damage in excess of $\$ 1000$ and, of these, about 530 collisions caused damage in excess of $\$ 5000$.

Assuming each incident to involve only one residential unit and using a 1970 total of $67,700,000$ residential units the following annual frequencies of occurrence are obtained:

(1) 600 collisions per million dwelling units.

(2) 86 collisions per million residential units causing non-auto property damage in excess of $\$ 1000$.

(3) 7.8 collisions per million residential units causing non-auto property damage in excess of $\$ 5000$.

The last frequency based on $\$ 5000$ property damage which is an order of magnitude less than the preceding one based on $\$ 1000$ property damage is thought to be the more meaningful estimate for severe building collisions.

\subsection{Sonic Boom [15]}

An aircraft flying at supersonic speeds generates shock waves which result in the acoustic phenomenon known as sonic boom. The shock wave created is propagated behind the aircraft in the shape of a cone (fig. 13). The surface of intersection of the cone with the ground, as shown in figure 13, may be referred to as the swath. The sonic boom is heard at all points within the swath and structures within this area are subjected to an overpressure. Both the swath and overpressure are affected by parameters such as: 
- aircraft specifications, i.e., size, shape. length, wing span, etc.,

- aircraft motion, i.e., altitude, speed and nature of maneuver,

- atmospheric conditions, i.e., temperature, ambient pressure, turbulence, etc.,

- nature of the terrain.

Existing data on damages caused by sonic boom have been generated, both accidentally and experimentally, in the United States almost exclusively by military aircraft. Some 41,617 sonic boom damage claims [18] totaling more than $\$ 20,000,000$ [38] were filed against the United States between 1956 and 1970 for damages allegedly caused by the military. This represents about one-third of the total number of complaints made but not all of which were filed. Payments totaling $\$ 1,716,639$ were made against 37 percent of the filed damage claims [18].

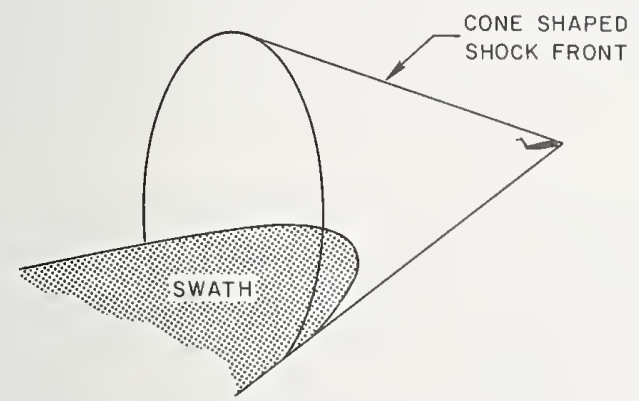

Figure 13. Sonic boom shock front.

At least 25 percent of these damage claims arose from monitored supersonic flights over builtup areas. For example, during a 6-month period in 1964 a total of 1253 booms were deliberately caused along a straight flight track passing over a northwest portion of Oklahoma City. These investigative test flights were sponsored by the Federal Aviation Administration and were undertaken by the Department of the Air Force. Peak overpressures between 1 and 4.4 psf with a median value of 1.2 psf resulted in 4901 damage claims being filed but only 287 payments totaling $\$ 123,061$ [18] were made.

An accidental boom occurred over Albuquerque during maneuvers in a 1969 air show by an $\mathrm{F}-4 \mathrm{E}$ aircraft. Reed [30] estimated that overpressures must have averaged more than 20 psf over about one square mile of the city. In spite of this relatively high overpressure, damage, although extensive, was apparently limited to glass breakage and cracked plaster.

A study [29] involving about 3000 complaints resulted in the damage breakdown shown in figure 14. Wiggins [38] reached similar conclusions in a study of damage payments arising from four separate accidental sonic boom incidents. Experimental programs such as the White Sands tests which, during 1964 and 1965, involved 1493 booms and overpressures as high as 38 psf $[31,39]$ produced only relatively minor damage in the buildings involved. In a follow-up study Wiggins [39] reported that some 7 years and 802 booms ( 56 of which were in the 8-20 psf range) later, any cumulative damage due to sonic boom was far outweighed by the effects of natural deterioration.

The available data indicate that the sonic boom damage which has occurred in the past has been largely "cosmetic" in nature. Thus, barring changes in aircraft size, type, and operating procedures, it is concluded that the sonic boom need not be considered as far as structural integrity is concerned.

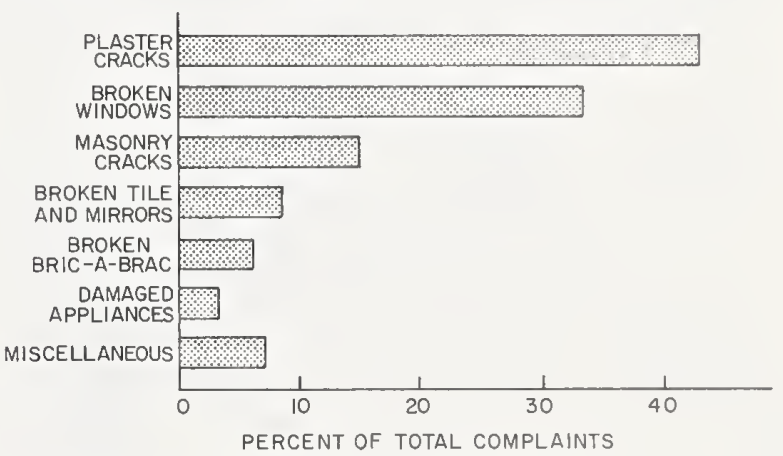

FigUre: 14. Breakdown of about 3000 complaints due to sonic booms as recorded in Air Force files [29].

\subsection{Aircraft Collision with Buildings [14]}

Aircraft traffic may be categorized as General Aviation, Certified Route and Supplemental Air Carrier, or Military aircraft. The category of General Aviation includes a wide variety of aircraft ranging in use from personal to crop dusting and accounts for about 80 percent [33] of all nonmilitary flying time. The category of Certified Route and Supplemental Air Carrier includes aircraft such as scheduled and non-scheduled commercial aircraft. The category of Military aircraft is self-explanatory. Accident statistics $[1,6,33]$ for the two categories of civilian aircraft 
are given in figure 15 for the years 1968 through 1971.

Upon request the National Transportation Safety Board analyzed all Civil Aviation accidents over the 7-year period 1964 to 1970 in order to establish the number of aircraft-building collisions, to ascertain the type of building or buildings involved and to obtain some idea of the nature of nonaircraft property damage. The results of this analysis [19] indicate an average of five incidents involving residences; i.e., single unit, double unit, or row-type housing. There were an average of eight incidents involving "buildings." This category of "buildings" includes residential buildings other than in the preceding category as well as buildings such as churches, schools, and office buildings.

During the 7-year reporting period there were two collisions involving high-rise apartment buildings [14]. In one instance a single engine plane struck a glancing blow at the sixteenth story level of a 30-story apartment building. Damage to the building was of a "cosmetic" nature. In the second instance a small aircraft impacted the airconditioning equipment at the top of a 16-story apartment building. In both cases the buildings were shrouded in fog and none of the building occupants were killed.

Collisions with buildings at airports occur more frequently than the off-airport accidents discussed here; however, these are considered beyond the scope of this report.

Available data from the U.S. military indicate that during the period 1962 to 1972 the Air Force recorded three accidents involving collisions with buildings. The Army recorded three accidents involving collisions with buildings during the period 1969 to 1972 . This averages out to less than one collision per year.

NTSB [3] figures also indicate that of all accidents involving large fixed wing civil aircraft over the 6-year period 1964 to 1969 , approximately 55 percent occurred within (on or over) the confines of the airport and an additional 15
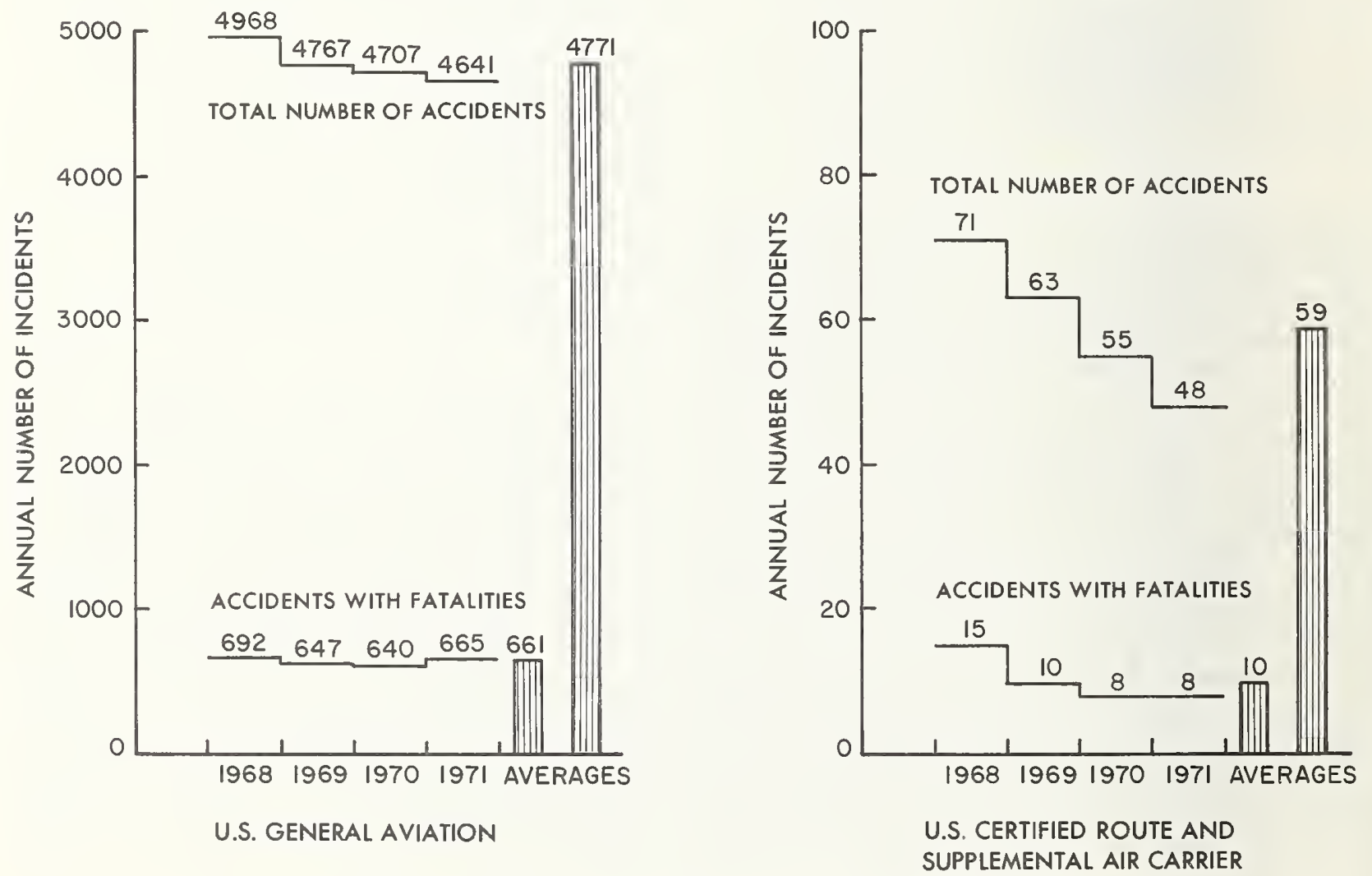

Figure 15. Aviation statistics for U.S. civil aviation $[I, 6,33]$. 
percent within 5 miles of the airport. The remaining 30 percent of the accidents occurred at distances of more than 5 miles from an airport. More than half, i.e., 55 percent, of the accidents occurring at distances greater than 5 miles from airports resulted in damage of some consequence. Thus the probability of aircraft accident and hence building collision is dependent upon location relative to the airport and the size (primarily height) of the building.

Assuming that each of the 13 or so aircraft with building collisions per year involved one residential unit and using a 1970 total of $67,700,000$ residential units, a high frequency estimate of about 2 collisions per 10 million residential units per year is obtained. A breakdown of this conservative estimate of total collision incidents into categories such as severe damage is not possible at this time. However, as described earlier, it is known that damage to the structure is not severe in each collision incident. Thus, in general, it is concluded that aircraft collision need not be specifically considered as an abnormal loading. However, buildings in close proximity to an airport may require a specific site analysis to be made.

\subsection{Hazardous Materials [35]}

Explosive incidents may occur in urban areas during the normal transportation of hazardous materials or during storage of such materials. The magnitude of the problem is illustrated by an accident that occurred in East St. Louis, Missouri on January 22, 1972 [32]. During a railroad yard operation, a tank car filled with propylene, a derivative of liquid petroleum gas, was punctured by another car. The released propylene formed an unconfined vapor cloud which subsequently exploded. Some 650 homes were damaged, 100 families were homeless, and an estimated 6.5 million dollars of damage occurred. Strehlow [36] tabulating 108 such explosions over a 42-year period contends that incidents such as the one described above are increasing.

Steele et al. [35] studied data on five different handling procedures for hazardous materials, i.e., (1) pipeline (except natural gas), (2) water carriers, (3) motor vehicles, (4) railroad, and (5) storage. On the whole they were unable to develop empirical evidence that determined whether or not such operations pose a threat to buildings. The trend toward increased volumes of materials shipped in proximity to structures raises the prospect of future incidents. However, it is thought that this source of abnormal loading need not be considered at this time.

\section{Evaluation of Data}

\subsection{Assumptions and Summary of Reviewed Data}

The following abnormal loads have been considered in this report:

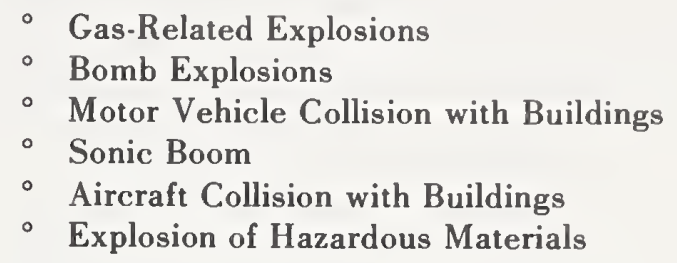

These loadings do not constitute a complete list of abnormal loadings which may occur. However, on the basis of the various surveys described earlier (see sec. 1), these loads are plausible potential sources of the initial failure which might lead to progressive collapse.

It has been roncluded earlier that the sonic boom, aircraft collision, and hazardous material handling do not usually constitute a problem for buildings. However, it is possible that certain building locations may require a site study.

The data for the gas explosion, bomb explosion, and vehicular collision may be discussed in terms of probability theory. The probability of structural failure due to abnormal loads, $P(F)_{A B}$, may be stated as

$$
\mathrm{P}(\mathrm{F})_{\mathrm{AB}}=\mathrm{P}(\mathrm{F} \mid \mathrm{AB}) \times \mathrm{P}(\mathrm{AB})
$$

where

$$
\begin{gathered}
\mathrm{P}(\mathrm{F} \mid \mathrm{AB})=\begin{array}{c}
\text { Probability of failure given an } \\
\text { abnormal load event }
\end{array} \\
\mathrm{P}(\mathrm{AB})=\begin{array}{c}
\text { Probability of occurrence of an } \\
\text { abnormal load event }
\end{array}
\end{gathered}
$$

The probability of occurrence of an abnormal load event, $\mathrm{P}(\mathrm{AB})$, is dependent on factors such as building location or type of service system but is independent of any particular type of building construction or procedure used in design. On the other hand, the probability of failure given an event, $\mathrm{P}(\mathrm{F} \mid \mathrm{AB})$, is a function of building type as well as the particular codes and standards used in 
its design and construction. Thus, statistics on failure due to abnormal loadings should include the frequency of occurrence of an event as well as the frequency of failure of a particular building type as a consequence of the event.

The total number of events, required to estimate the probability of occurrence, $\mathrm{P}(\mathrm{AB})$, is usually available for the loadings described in this report. However, the probability of failure given the event, $\mathrm{P}(\mathrm{F} \mid \mathrm{AB})$, is not available. Instead, the number of incidents causing damage in excess of a specific level (as measured in dollars) or a brief description of damage is usually provided. There is rarely complete information on the type or number of structures affected or an adequate description of their damage. There are also no available U.S. data which provide a correlation between a specified damage level and a corresponding damage loss in dollars. Finally, there are no data on the load characteristics of the actual events.

In order to compare the data for the gas explosion, bomb explosion, and vehicular collision, the following definitions of damage (similar to those for bomb explosions) are adopted for the remainder of this report:

(1) Total incidents-All incidents involving a particular abnormal load.

(2) Intermediate or greater damage-Damage in excess of $\$ 1000$ for gas explosions, $\$ 1000$ for vehicular collision, or described as intermediate or greater for bomb explosions. This level implies fairly extensive damage such as walls blown down.

(3) Severe damage-Damage in excess of $\$ 10,000$ for gas explosions; $\$ 5000$ for vehicular collision; or described as severe for bomb explosions. This level implies extensive structural damage, such as unit destroyed.

These definitions involve some arbitrary judgment because of the limitations on the available data. However, it is interesting to note that Taylor and Alexander [37] collected data in which some 122 gas explosions caused damage judged as significant (similar to the category of severe used in this report) with an estimated total loss of repair $£ 500,000$. This is an average of $£ 4.100$ per incident or about $\$ 10,200$ (at an exchange rate of $\$ 2.50$ ) in terms of the 1971,1972 collection period. Although circumstances differ considerably, this lends further substance to the judgments made above which correlate damage to dollar amounts. The estimated annual frequencies for the categories defined above are summarized in figure 16.

The annual frequencies shown in figure 16 may be discussed in terms of eq (1). The probability of occurrence, $\mathrm{P}(\mathrm{AB})$, is readily obtained from the data in the figure. Since data on $P(F \mid A B)$ and $P(F)_{A B}$ are not available, data have been presented in a form resulting in the probability of damage above a specified level, $P(D)_{p}$,

$$
P(D)_{p}=P\left(D_{p} \mid A B\right) \times P(A B)
$$

where

$\mathrm{P}\left(\mathrm{D}_{\mathrm{p}} \mid \mathrm{AB}\right)=$ Probability of damage above a specified level given an abnormal load event

$\mathrm{P}(\mathrm{AB}) \quad=$ Probability of occurrence of an abnormal load event

$\mathbf{p}$

$=$ Subscript indicating the specified damage level, e.g., intermediate or severe.

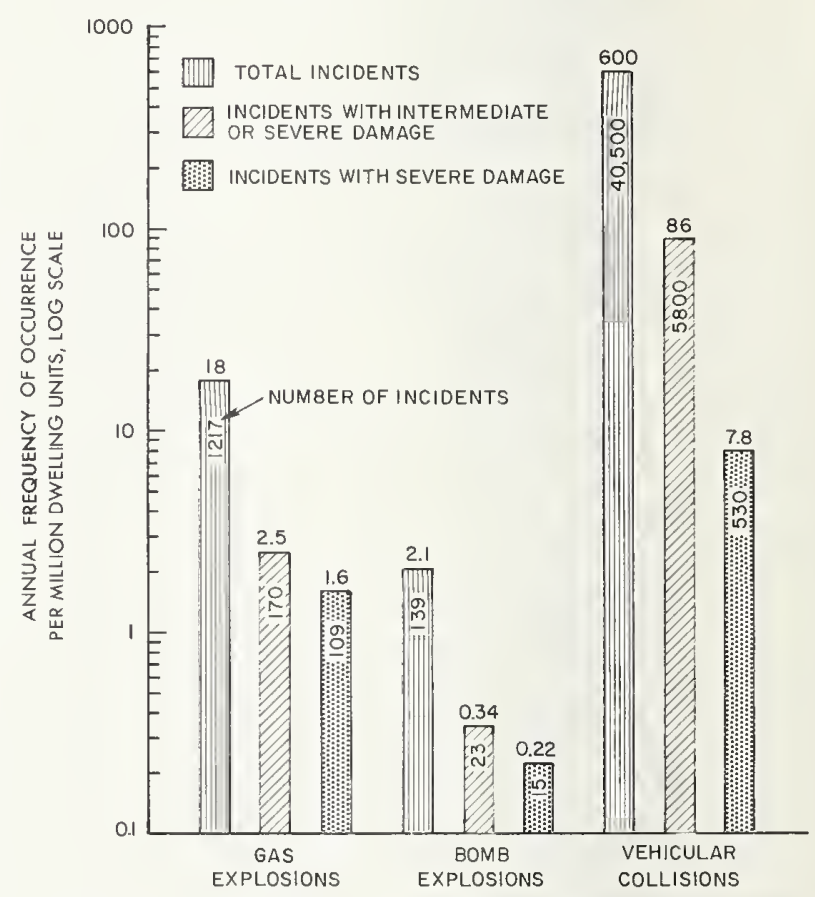

Figure 16. Summary of annual probabilities of abnormal loadings for 1970 . 
TABLE 2. Calculated estimates of $P\left(D_{D} \mid A B\right)$

\begin{tabular}{|c|c|c|c|c|c|}
\hline \multirow{3}{*}{$\begin{array}{l}\text { Abnorinal } \\
\text { Loading }\end{array}$} & \multirow[b]{3}{*}{$\mathrm{P}(\mathrm{AB})$} & \multicolumn{2}{|c|}{$P(D)_{0}$} & \multicolumn{2}{|c|}{ Calculated $P\left(D_{p} \mid A B\right)$} \\
\hline & & Based On & Based On & Based On & Based On \\
\hline & & Int. Damage & Severe Damage & Int. Damage & Severe Damage \\
\hline
\end{tabular}

$\begin{array}{lcccccccc}\text { Gas Expl. } & 18 & \times 10^{-6} & 2.5 & \times 10^{-6} & 1.6 & \times 10^{-6} & 0.14 & 0.089 \\ \text { Bomb Expl. } & 2.1 & \times 10^{-6} & 0.34 & \times 10^{-6} & 0.22 & \times 10^{-6} & 0.16 & 0.11 \\ \text { Veh. Coll. } & 600 & \times 10^{-6} & 86.0 & \times 10^{-6} & 7.8 & \times 10^{-6} & 0.14 & 0.013\end{array}$

NOTE: The probabilities listed are per $d$ welling unit.

The terms $P(D)_{p}$ and $P(A B)$ are obtainable from the data in figure 16 and $P\left(D_{p} \mid A B\right)$ may be computed using eq (2) rewritten as

$$
P\left(D_{p} \mid A B\right)=\frac{P(D)_{p}}{P(A B)}
$$

Using this equation, values for $P\left(D_{p} \mid A B\right)$ were computed and are shown in table 2.

The probabilities of any one of the abnormal events resulting in intermediate damage is on the order of 15 percent. However, for severe damage, the probabilities for the gas and bomb explosions are about 10 percent but only about 1 percent for the vehicular collision. This merely indicates that, given one of the three abnormal loadings, the gas or bomb explosion is more likely to result in severe structural damage than the vehicular collision.

Since abnormal loads are quite rare and reasonably uniformly distributed in time, it may be assumed that their occurrence is a Poisson process. If $\mathrm{N}(\mathrm{T})$ is the number of abnormal loads occurring in the time interval $\mathrm{T}$, then

$P[N(T)=n]=\frac{(\lambda T)^{n} e^{-\lambda T}}{n !}$

where $\lambda$ is the mean rate of occurrence of abnormal loads; for small values of $\lambda, \lambda=P(A B)$. Denoting $p_{p}=$ $\mathrm{P}(\mathrm{F} \mid \mathrm{AB})$, the number of failed elements $\mathrm{N}_{\mathrm{F}}$ in $\mathrm{T}$ is also a Poisson process with the same probability law as equation 3 , replacing $\lambda$ with $\lambda p_{p}$. The probability of one or more structural elements failing from gas explosions is then $\mathrm{P}\left[\mathrm{N}_{\mathrm{F}}(\mathrm{T})>0\right] \approx \mathrm{p}_{\mathrm{f}} \lambda \mathrm{T}$.

With the lifetime $T$ typically about 60 years, $\lambda \approx 18$ $\times 10^{-6}$, and assuming that $\mathrm{P}\left(\mathrm{D}_{\text {severe }} \mid \mathrm{AB}\right) \approx \mathrm{P}(\mathrm{F} \mid \mathrm{AB})$ $\approx 0.1$ from table 2 , the probability of failure due to abnormal load during the life of the structure is about $1.1 \times 10^{-4}$. This compares unfavorably with the probability of failure under normal loads, which is frequently taken to be of the order of $10^{-5}$ or less. This is a crude comparison, but it does provide a "feel" for the meaning of the numbers. It should atso be noted that the statistics do not differentiate between building types or the regulations used in their design.

\subsection{Effect of Building Size}

The probability of an abnormal loading event occurring in a building is likely to increase with the building size. Thus the probability of a gas or bomb explosion is assumed to increase in proportion with the number of units in a building. In the case of the vehicular collision, it is assumed that only the ground story is usually accessible to a vehicle and that the probability of collision is proportional only to the number of units at ground level.

The effect of building size on the probability of a gas explosion occurring in the building is shown in figure 17 by plotting probability versus the number of dwelling units (the probabilities were obtained by multiplying the appropriate data in figure 16 by the number of residential units). Auxiliary axes are provided to indicate the number of stories when there are $5,10,15$ or 20 dwelling units per story.

A data point for an explosion in a building the size of Ronan Point (see sec. 1) is shown based on an annual frequency of 2.2 severe gas-related explosions per million dwelling units (Great Britain data, see ref. [17]) and a 22-story high building with $5 \mathrm{~d}$ welling units per story. Note that the point is very close to the U.S. data for explosions causing severe damage. Similar plots are presented in figures 18 and 19 for bomb explosions and vehicular collisions, respectively. The "Ronan Point" estimate is included for reference.

The variation of the probability for the severe abnormal loading events of figures 17,18 , and 19 are summarized in figure 20 for comparison. Since the data for vehicular collisions were taken proportional to the number of units at the ground level rather than the number of units in the building, comparisons can only be made at discrete points. Thus, the horizontal lines shown in 
figure 20, which indicate probability of severe collision, are maximums for buildings with the number of units per story shown encircled in the figure. For instance, assuming 10 units/story and reading the appropriate axis, it may be seen that the probability for a gas explosion exceeds a vehicular collision for buildings greater than about
5 stories in height. It can be shown by reading the appropriate axis, that this height of 5 stories is independent of the number of units per story. Similarly bomb explosions exceed vehicular collisions for buildings over 35 stories in height. This height of 35 stories is independent of the number of units per story.

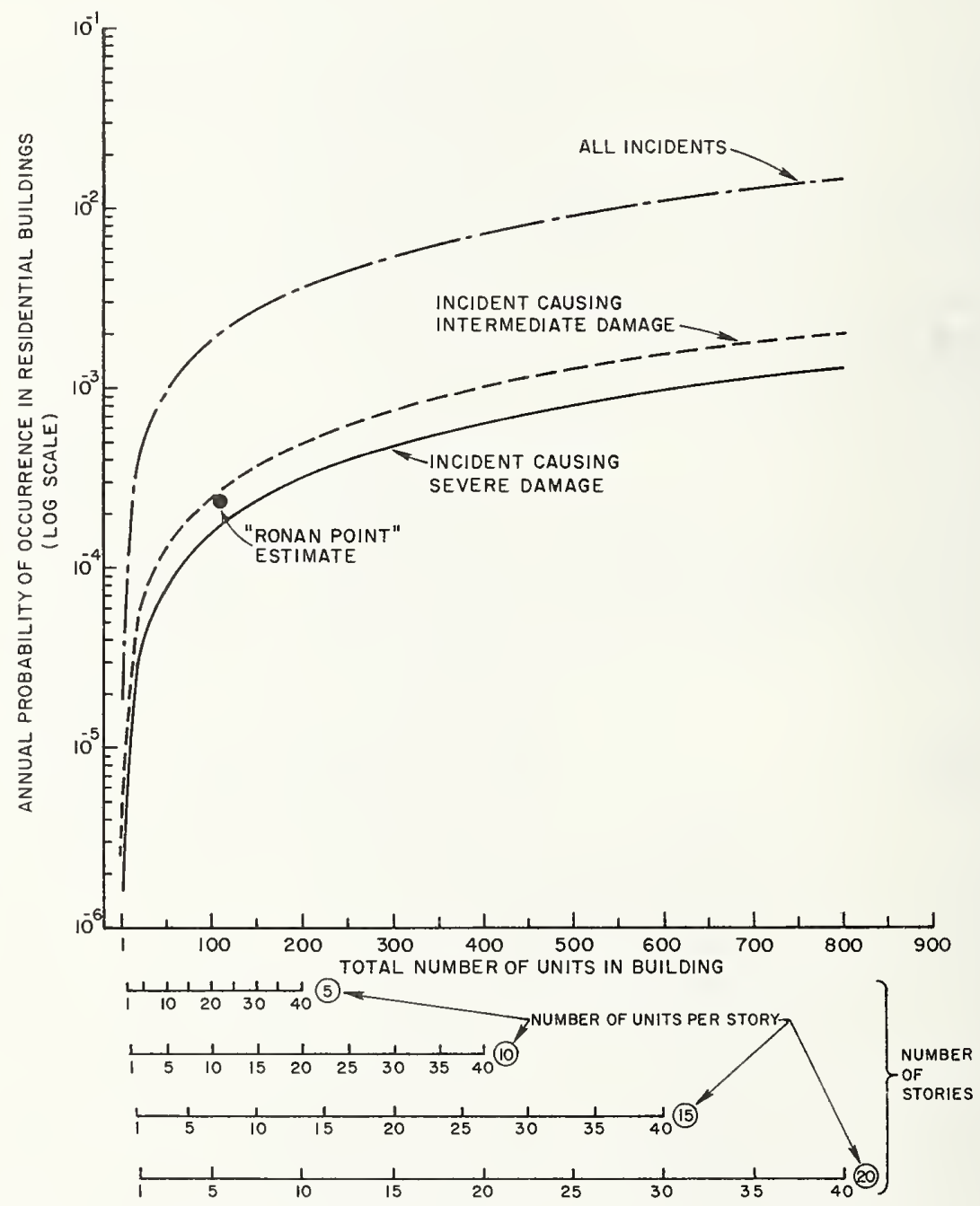

FICURE 17. Variation of probability of gas-related explosions with increasing size of residential building. 


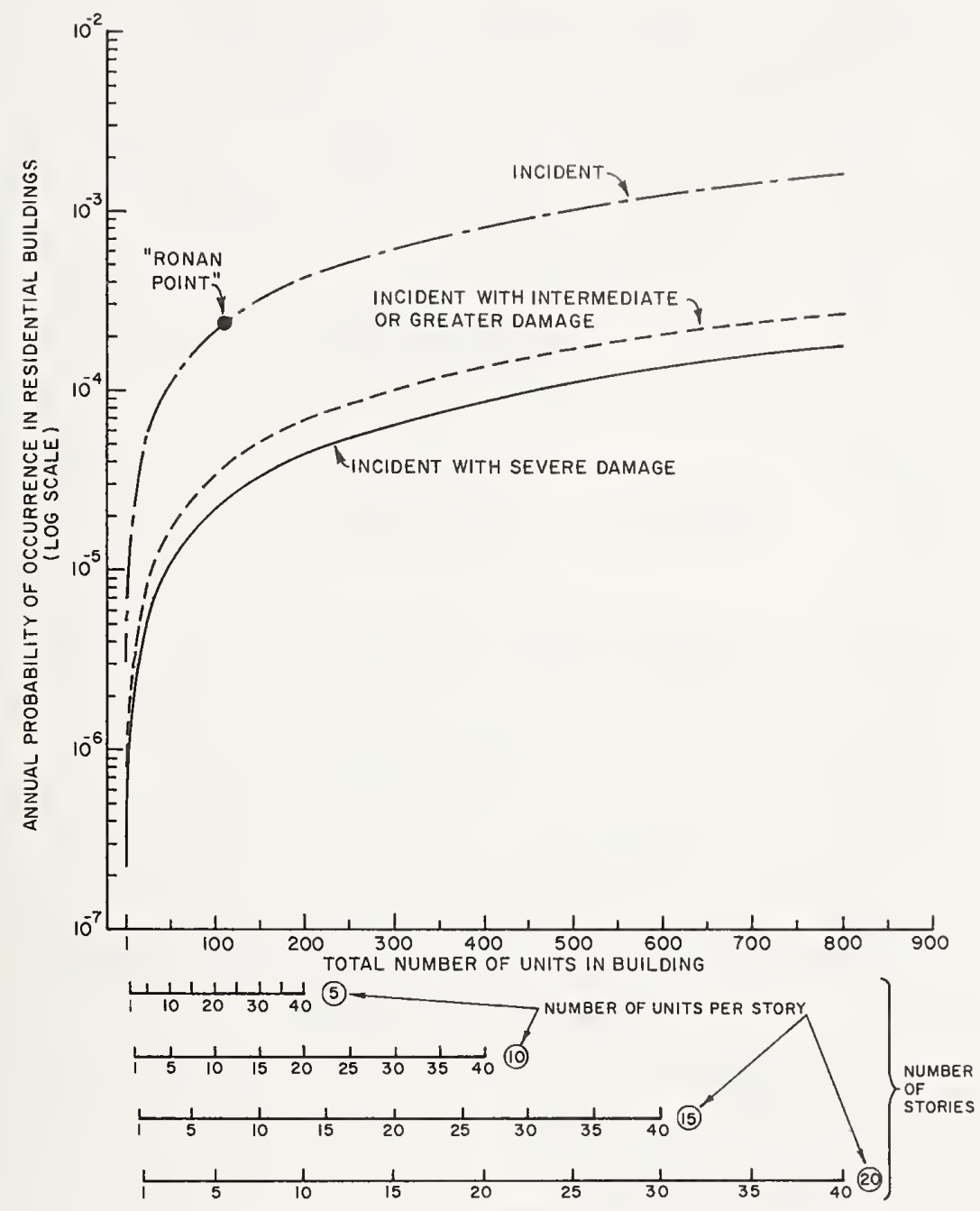

Ficur: 18. Variation of probability of bomb explosions with increasing size of residential building. 


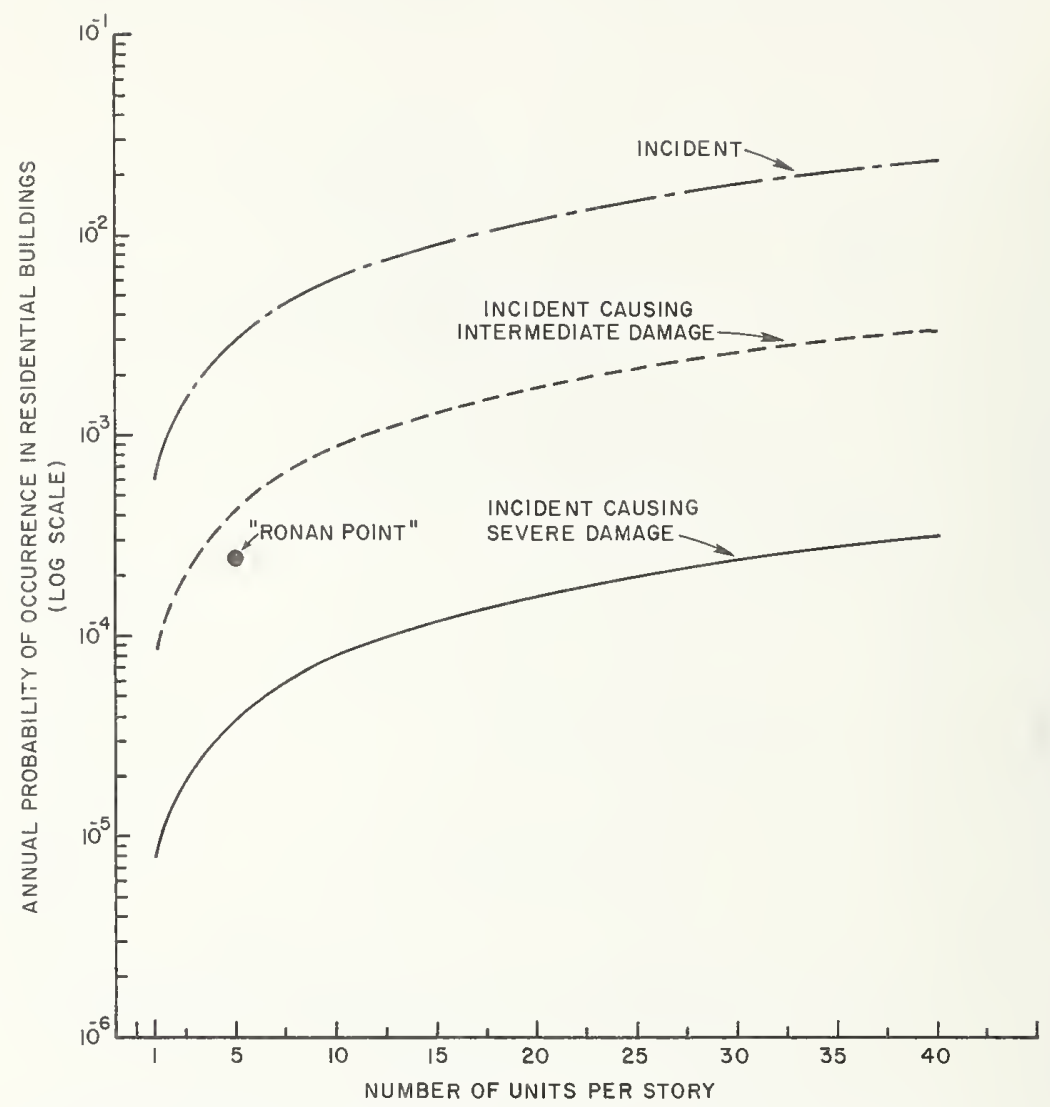

FIGURE. 19. Variation of probability of vehicular collision with increasing size of residential building. 


\subsection{Load Data}

The previously cited report by Taylor and Alexander presented data on peak pressure reached in 122 gas explosion incidents judged as severe. Each of the incidents was investigated and a low and high estimate for pressure was assigned based on characteristics of physical damage. Their results are shown in figure 21 .

As expected, "large peak pressures" occur only rarely. In particular the pressure of $34 \mathrm{kN} / \mathrm{m}^{2}(5$ psi), which is mentioned frequently in the literature on progressive collapse, was exceeded only four times (at most) in the two years of their survey.

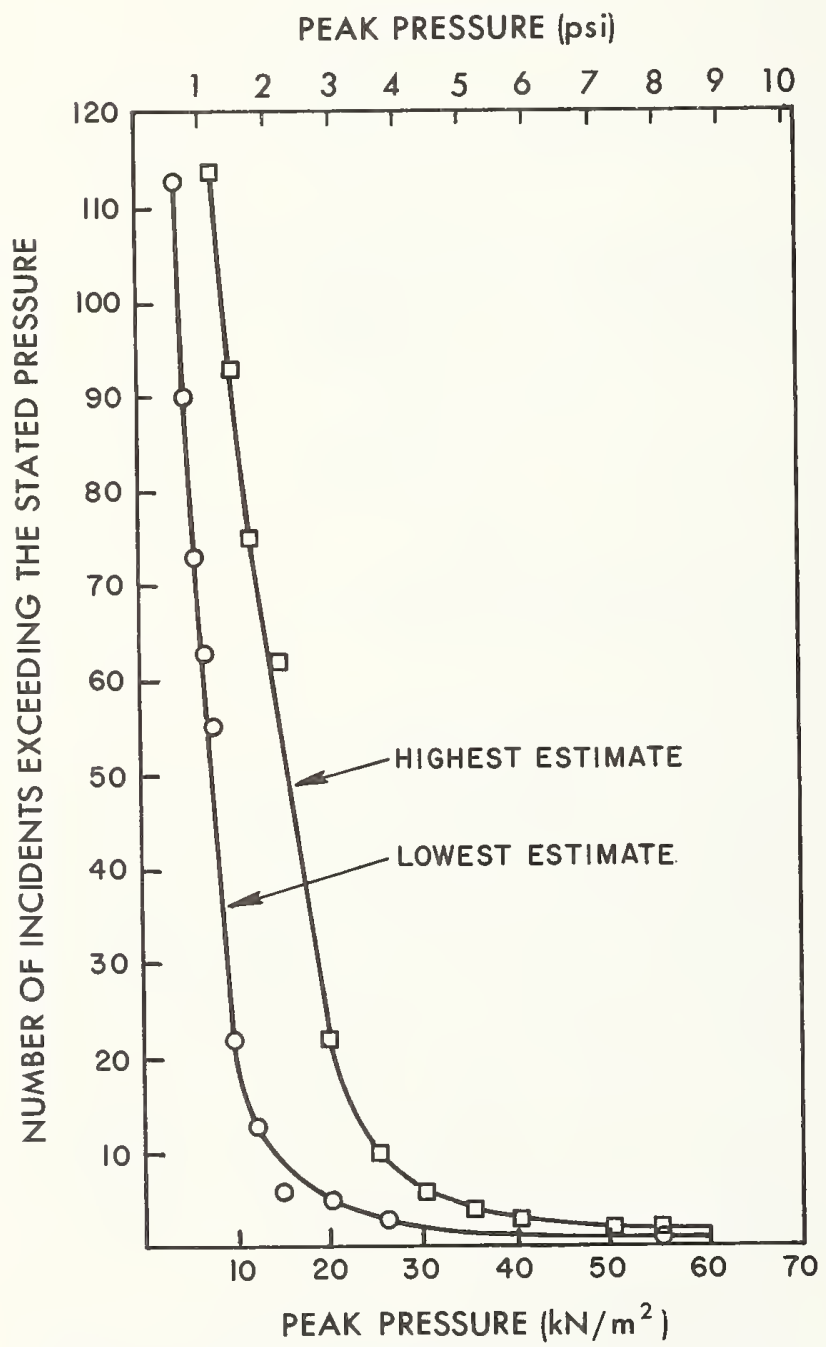

Figure 21. Frequency-severity curve for the significant events in Taylor and Alexander's survey [38].

\section{Conclusions and Concluding Remarks}

\subsection{Conclusions}

The purpose of this report has been to discuss plausible sources of abnormal loading events and to estimate the risk of the loadings in residential building design with regard to progressive collapse.

A number of assumptions (sec. 4.1) have been necessary in order to analyze the data presented in this report. These are related primarily to the lack of detailed descriptions of damage accompanying the various abnormal loading events and the lack of detailed descriptions of the buildings involved in the incidents. In spite of these limitations the following conclusions are considered valid. Where numerical data are presented they are thought to be the correct order of magnitude.

1. At this time it appears unnecessary to include sonic boom, aircraft collision, and hazardous material accidents in design for progressive collapse for typical building locations. It may be necessary in some instances to prepare site studies, as for buildings located adjacent to airports.

2. Gas explosions occur with an annual frequency of 18 events per million dwelling units with an annual frequency of 1.6 events per million dwelling units causing severe damage. Based upon the assumption that severe damage is equivalent to structural failure, there is a 9 percent probability of local structural failure, given that the event occurs.

3. Bomb explosions occur with an annual frequency of 2.1 events per million dwelling units with an annual frequency of 0.22 events per million dwelling units causing severe damage. Based on the assumption that severe damage is equivalent to structural failure, there is an 11 percent probability of element failure given that the event occurs.

4. Vehicular collisions with buildings occur with an annual frequency of 600 events per million dwelling units with an annual frequency of 6.8 events per million dwelling units causing severe damage. Based on the assumption that severe damage is equivalent to structural failure, there is a 1 percent probability of element failure given that the event occurs. 
5. The probabilities for the preceding three events increase with increasing building size as shown in figures 17, 18, 19, and 20 . For the case of severe damage, the gas explosion event approaches an annual probability of $1 \times 10^{-3}$ and exceeds the bomb explosion event by an order of magnitude and is greater than that for vehicular collisions for buildings in excess of five stories in height.

6. No load data for actual events are available except for Taylor and Alexander's survey in the United Kingdom (fig. 21) which considered primarily data for gas explosions. At the most, 3 percent of these events had peak pressures in excess of $34 \mathrm{kN} / \mathrm{m}^{2}(5 \mathrm{psi})$. This pressure has been frequently mentioned in progressive collapse literature.

7. The statistical reporting of abnormal loading events needs to be considerably improved in order to obtain load data and damage data in particular types of building construction.

\subsection{Concluding Remarks}

In dealing with events which have a low probability of occurrence but potentially severe consequences it is necessary to consider what society is willing to accept. Starr [34] has suggested that social activities consist of "voluntary" (consciously assumed) and "involuntary" (unconsciously assumed) activities. His data indicated that the public will accept a "voluntary" type of risk which is on the order of 1000 times greater than "involuntary" risks. He finally concluded that "we are loathe to let others do unto us what we happily do to ourselves." There is a parallel here with progressive collapse if it is accepted that living in one's home and being exposed to death falls into the category of "involuntary" action. The thought that a person in one dwelling unit should be exposed to death as a consequence of an abnormal loading event in another dwelling unit appears to be unacceptable. However, the risk involved should be kept at a level associated with the necessary or "involuntary" activities.

The probability of failure $\mathrm{P}(\mathrm{F})_{\mathrm{AB}}$ as expressed in eq (l) consists of two terms. The structural designer has very little control over the probability of an abnormal event, $\mathrm{P}(\mathrm{AB})$. The probability of the event may be reduced by other action such as improvements of pipeline safety in the case of gas explosions. However, the structure can be designed so that the probability of failure given the occurrence of an event $\mathrm{P}(\mathrm{F} \mid \mathrm{AB})$, is acceptably small. This approach of designing the structure to resist specified loads has been referred to as "soecific local resistance." Since the frequency of a gas explosion exceeds the other abnormal loading events by an order of magnitude, it is suggested that this loading may be used as the design basis.

A second approach, when it is infeasible to design the critical elements with sufficient strength, is to design the structure in such a way that if an element fails, the resulting forces may be redistributed without inducing progressive collapse. This approach has been referred to as the "alternate path" method.

\section{Acknowledgments}

The cooperation of the following individuals and organizations in gathering the statistics used in this report is gratefully acknowledged:

- Jane P. Morton, International Association of Chiefs of Police

- Federal Bureau of Investigation

- American Gas Association

- Mr. Starke Jett, National Transportation Safety Board

- Major William M. Price, U.S. Army Agency for Aviation Safety

- Colonel Ray C. Staley, Department of the Army

- Commander R. A. Eldridge, Naval Safety Center, Department of the Navy

The authors would like to thank Dr. B. R. Ellingwood, Dr. C. Culver, Mr. S. R. Hastings, and Dr. J. G. Kowalski of the Center for Building Technology, National Bureau of Standards; Mr. L. A. Issen of the Center for Fire Research, National Bureau of Standards; and Mr. W. J. Werner of the Office of Policy Development and Research, Department of Housing and Urban Development for their review of the manuscript. 


\section{References}

[1] Accident and Fatality Rates, 1962-1972. National Transportation Safety Board, Washington, D.C., (Analysis dated 23 January 1973).

[2] "Accident Facts," National Safety Council, Chicago, Illinois, 1971.

[3] Airport Proximity Study, U.S. Civil Aviation 1964-1969. National Transportation Safety Board, Washington, D.C.

[4] Allen, D. E., and Schriever, W. R., "Progressive Collapse, Abnormal Loads, and Building Codes," Structural Failures: Modes, Causes, Responsibilities, American Society of Civil Engineers, New York, 1973.

[5] Arthur D. Little Inc., "Public Safety and Gas Distribution," Research Report prepared for the American Gas Association, Washington, D.C., December 1967.

[6] Aviation Forecasts Fiscal Years 1973-1984, Department of Transportation, Federal Aviation Administration, September 1972.

[7] Baker, J. F., Williams, E. L., and Lax, D., "The Design of Framed Buildings Against High Explosive Bombs," The Civil Engineer in War, Institution of Civil Engineers, Vol. 3, London, 1948.

[8] “Bomb Accidents in California During 1971," Division of Law Enforcement, Organized Crime and Criminal Intelligence Branch, California Department of Justice, Sacramento, California.

[9] "Bomb Summary," Uniform Crime Reports, Federal Bureau of Investigation, National Bomb Data Center, 1972.

[10] "Bomb Summary," Uniform Crime Reports, Federal Bureau of Investigation, National Bomb Data Center, 1973.

[11] Bureau of the Census, "1960 Census of Housing. Detailed Housing Characteristics, United States Summary Report," U.S. Department of Commerce, Washington, D.C., U.S. Government Printing Office.

[12] Bureau of the Census, "1970 Census of Housing. Detailed Housing Characteristics, United States Summary Report," U.S. Department of Commerce, Washington, D.C., U.S. Government Printing Office.

[13] Burnett, E. F. P., "Abnormal Loadings and the Safety of Buildings," Industrialization In Concrete Building Construction, Publication SP 48, American Concrete Institute, Detroit, 1975.

[14] Burnett, E. F. P., "Aircraft Accidents and Building Safety," NBS-GCR 76-67, Center for Building Technology, National Bureau of Standards, Washington, D.C. 20234, August 1973.

[15] Burnett, E. F. P., "Sonic Boom and Considerations of Building Safety," NBS.GCR 76-68, Center for Building Technology, National Bureau of Standards, Washington, D.C. 20234, August 1973.

[16] Burnett, E. F. P., "The Structural Implications of Explosive Bombing Incidents," NBS-GCR 76-66, Center for Building Technology, National Bureau of Standards, Washington, D.C. 20234, August 1973.

[17] Burnett, E. F. P., Somes, N. F., and Leyendecker, E. V., "Residential Buildings and Gas-Related Explosions," NBSIR 73-208, Center for Building Technology,
National Bureau of Standards, Washington, D.C. 20234, June 1973.

[18] Clarkson, B. L. and Mayes, W. H., "Sonic Boom Induced Building Structure Response Including Damage," Journal of the Acoustical Society of America, Vol. 51, No. 2, (Part 3), February 1972.

[19] Collisions with Buildings, U.S. Civil Aviation 1964-1970, National Transportation Safety Board, Washington, D.C. (Analysis Dated March 1972).

[20] Fribush, S. L., Bowser, D., and Chapman, R., "Estimates of Vehicular Collisions with Multi-Story Residential Buildings," NBSIR 73-175, National Bureau of Standards, Washington, D.C., April 1973.

[21] Fry, J. E., "Gas Explosions Attended by Fire Brigades in Dwellings," Journal of the Institute of Fuel, England, August-September 1971.

[22] Gas-Facts-A Statistical Record of the Gas Utility Industry in 1970, American Gas Association, Washington, D.C., 1970.

[23] Griffiths, H., Pugsley, A., and Saunders, D., Report of the Inquiry into the Collapse of Flats at Ronan Point, Canning Town, Her Majesty's Stationary Office, London, England, 1968.

[24] Ligtenberg, F. K., "Structural Safety and Fire (1.3)," Build International, London, Vol. 4, No. 5, September/October 1971.

[25] McGuire, W., "Prevention of Progressive Collapse," ASCE-IABSE Regional Conference on Tall Buildings, Bangkok, January 1974.

[26] "Monthly Summary Reports, January through December 1971," National Bomb Data Center, International Association of Chiefs of Police, Gaithersburg, Maryland.

[27] Morton, J. P., “Bombing Incident Target Analysis, July 1970-December 1971," International Association of Chiefs of Police, Gaithersburg, Maryland, 1973.

[28] Morton, J. P. and Persinger, G. S., "Bombing in the United States, July 1970-June 1971," The National Bomb Data Center, International Association of Chiefs of Police Inc., Gaithersburg, Maryland, 1971.

[29] Nixon, C. W. and Hubbard, H. H., "Results of USAF. NASA-FAA Flight Program to Study Community Responses to Sonic Booms in the Greater St. Louis Area," NASA TN D-2705, May 1965.

[30] Reed, J. W., "The Thunderbird Boom Incident," Albuquerque, November 16, 1969. Sandia Laboratories Technical Memorandum, SC-TM-70-592, January 1971.

[31] Sharpe, R. L. and Garrison Kost, "Structural Response to Sonic Boom," Proc. A.S.C.E., Journal of Structural Division, Vol. 97, No. ST4, April 1971.

[32] Somes, N. F., "Abnormal Loadings on Buildings and Progressive Collapse," a paper in "Building Practices for Disaster Mitigation," National Bureau of Standards, Building Science Series 46, U.S. Government Printing Office, Washington, D.C. 20402, February 1973.

[33] Statistical Handbook of Aviation, Department of Transportation, Federal Aviation Administration, U.S. Government Printing Office, Washington, D.C. 20402, 1970.

[34] Starr, C., "Social Benefit versus Technological Risk," Science, Washington, D.C., Vol. 165, No. 3899, September 19, 1969. 
[35] Steele, W. A., Bowser, D., and Chapman, R. E., "The Incidence of Hazardous Material Accidents During Transportation and Storage," NBSIR 73-412, National Bureau of Standards, Washington, D.C. 20234, November 1973.

[36] Strehlow, R. A., "Unconfined Vapor Cloud ExplosionsAn Overview," Report AAE TR 72-1, UILU.ENG. 72 0501, Aeronautical and Astronautical Engineering Department, University of Illinois, Urbana, Illinois, February 1972.
[37] Taylor, N. and Alexander, S, J., "Structural Damage in Buildings Caused by Gaseous Explosions and Other Accidental Loadings," C.P 45/74, Building Rosearch Establishment, England, March 1974.

[38] Wiggins, Jr., J. I1., Effects of Sonic Boom, J. II. Wiggins Co., Palos Verdes Estates, California, 1969.

[39] Wiggins, Jr., J. H., "Sonic Boom and Natural Deterioration: Effects on Buildings. White Sands, N.M. Structural Survey," Department of Transportation, F.A.A. Report No. FAA.RH).72.25, February 1972. 
NBS.114A (REV, 7-73)

\begin{tabular}{|c|c|c|c|}
\hline $\begin{array}{l}\text { IJ.S. JEPT. OF COMM. } \\
\text { BIBLIOGRAPHIC DATA } \\
\text { SHEET }\end{array}$ & $\begin{array}{l}\text { 1. PUBLICATION OR REPORT NO. } \\
\text { NBS BSS }-89\end{array}$ & $\begin{array}{l}\text { 2. Gov't Accession } \\
\text { No. }\end{array}$ & 3. Recipient's Accession No. \\
\hline \multirow{2}{*}{\multicolumn{3}{|c|}{ THE INCIDENCE OF ABNORMAL LOADING IN RESIDENTIAL BUILDINGS }} & $\begin{array}{l}\text { 5. Publication Date } \\
\text { December } 1976 \\
\end{array}$ \\
\hline & & & 6. Performing Organization Code \\
\hline \multicolumn{3}{|l|}{ 7. AUTHOR(S) } & 8. Performing Organ. Report No. \\
\hline \multicolumn{3}{|c|}{$\begin{array}{l}\text { Edgar V. Leyendecker and Fric } F \cdot \frac{P}{\text { Burnet }} \\
\text { 9. PERFORMING ORGANIZATION NAME AND ADDRESS }\end{array}$} & $\begin{array}{l}\text { 10. Project/Task/Work Unit No. } \\
4618488\end{array}$ \\
\hline \multicolumn{3}{|c|}{$\begin{array}{l}\text { NATIONAL BUREAU OF STANDARDS } \\
\text { DEPARTMENT OF COMMERCE } \\
\text { WASHINGTON, D.C. } 20234\end{array}$} & $\begin{array}{l}\text { 11. Contract/Grant No. } \\
\text { IAA-H-37-72 } \\
\text { Task } 408\end{array}$ \\
\hline \multirow{2}{*}{\multicolumn{3}{|c|}{$\begin{array}{l}\text { 12. Sponsoring Organization Name and Complete Address (Street, City, State, ZIP) } \\
\text { Division of Energy, Building Technology and Standards } \\
\text { Office of Policy Development and Research } \\
\text { Dept. of Housing and Urban Development } \\
\text { Washington, D.C. } 20410\end{array}$}} & $\begin{array}{l}\text { 13. Type of Report \& Period } \\
\text { Covered } \\
\text { Final }\end{array}$ \\
\hline & & & 14. Sponsoring Agency Code \\
\hline
\end{tabular}

15. SUPPLEMENTARY NOTES

This report supersedes NBSIR 76-1048; Library of Congress Card Number: 76-26684

16. ABSTRACT (A 200-word or less factual summary of most significant information. If document includes a significant bibliography or literature survey, mention it here.)

The findings of an analysis of available U.S. statistics concerning the incidence of abnormal loading events in residential buildings are presented. The study evaluates natural gas explosions, bomb explosions, motor vehicle collision, sonic boom, aircraft collision, and explosion of hazardous materials.

It is concluded that the gas related explosion, bomb explosion, and vehicular collision are of significance in building design for progressive collapse. Of these, the natural gas explosion is the most significant in terms of incidence. The gas explosion causing severe damage occurs with an annual frequency of 1.6 per million dwelling units and approaches a probability of $1 \times 10^{-3}$ per apartment building per year.

17. KEY WORDS (six to twelve entries; alphabetical order; capitalize only the first letter of the first key word unless a proper name; separated by semicolons)

Bombs; building codes; design criteria; explosions; gas; hazardous materials; loads; progressive collapse; sonic boom; vehicular collision.

18. AVAILABILITY

For Official Distribution. Do Not Release to NTIS

Q Order From Sup. of Doc., U.S. Government Printing Office

Washington, D.C. 20402, SD Cat. No.CI3.2972:89

Order From National Technical Information Service (NTIS) Springfield, Virginia $2215 \mathrm{I}$

\begin{tabular}{|l|c|}
\hline $\begin{array}{l}\text { 19. SECURITY CLASS } \\
\text { (THIS REPURT) }\end{array}$ & $\begin{array}{c}\text { 21. NO. OF PAGES } \\
31 \\
\text { UNCL ASSIFIED }\end{array}$ \\
\hline $\begin{array}{l}\text { 20. SECURITY CLASS } \\
\text { (THIS PAGE) }\end{array}$ & $\begin{array}{c}\text { 22. Price } \\
75 c\end{array}$ \\
\hline UNCLASSIFIED & \\
\hline
\end{tabular}




\section{ANNOUNGEMENT OF NEW PUBLICATIONS IN BUILDING SCIENCE SERIES}

Superintendent of Documents, Government Printing Office, Washington, D.C., 20402

Dear Sir:

Please add my name to the announcement list of new publications to be issued in the series: National Bureau of Standards Building Science Series.

Name

Company

Address.

City State Zip Code

(Notification key N-339) 



\section{PERIODICALS}

JOURNAL OF RESEARCH reports National Bureau of Standards research and development in physics, mathematics, and chemistry. It is published in two sections, available separately:

- Physics and Chemistry (Section A)

Papers of interest primarily to scientists working in these fields. This section covers a broad range of physical and chemical research, with major emphasis on standards of physical measurement, fundamental constants, and properties of matter. Issued six times a year. Annual subscription: Domestic, $\$ 17.00$; Foreign, $\$ 21.25$.

- Mathematical Sciences (Section B)

Studies and compilations designed mainly for the mathematician and theoretical physicist. Topies in mathematical statistics, theory of experiment design, numerical analysis, theoretical physics and chemistry, logical design and programming of computers and computer systems. Short numerical tables. Issued quarterly. Annual subscription: Domestic, $\$ 9.00$; Foreign, $\$ 11.25$.

DIMENSIONS/NBS (formerly Technical News Bulletin)-This monthly magazine is published to inform scientists, engineers, businessmen, industry, teachers, students, and consumers of the latest advances in science and technology, with primary emphasis on the work at NBS. The magazine highlights and reviews such issues as energy research, fire protection, building technology, metric conversion, pollution abatement, health and safety, and consumer product performance. In addition, it reports the results of Bureau programs in measurement standards and techniques, properties of matter and materials, engineering standards and services, instrumentation, and automatic data processing.

Annual subscription: Domestic, $\$ 9.45$; Foreign, $\$ 11.85$.

\section{NONPERIODICALS}

Monographs-Major contributions to the technical literature on various subjects related to the Bureau's scientific and technical activities.

Handbooks-Recommended codes of engineering and industrial practice (including safety codes) developed in cooperation with interested industries, professional organizations, and regulatory bodies.

Special Publications-Include proceedings of conferences sponsored by NBS, NBS annual reports, and other special publications appropriate to this grouping such as wall charts, pocket cards, and bibliographies.

Applied Mathematics Series-Mathematical tables, manuals, and studies of special interest to physicists, engineers, chemists, biologists, mathematicians, computer programmers, and others engaged in scientific and technical work.

National Standard Reference Data Series-Provides quantitative data on the physical and chemical properties of materials, compiled from the world's literature and critically evaluated. Developed under a world-wide program coordinated by NBS. Program under authority of National Standard Data Act (Public Law 90-396).
NOTE: At present the principal publication outlet for these data is the Journal of Physical and Chemical Reference Data (JPCRD) published quarterly for NBS by the American Chemical Society (ACS) and the American Institute of Physics (AIP). Subscriptions, reprints, and supplements available from ACS, 1155 Sixteenth St. N.W., Wash. D. C. 20056.

Building Science Series-Disseminates technical information developed at the Bureau on building materials, components, systems, and whole structures. The series presents research results, test methods, and performance criteria related to the structural and environmental functions and the durability and safety characteristics of building elements and systems.

Technical Notes-Studies or reports which are complete in themselves but restrictive in their treatment of a subject. Analogous to monographs but not so comprehensive in scope or definitive in treatment of the subject area. Often serve as a vehicle for final reports of work performed at NBS under the sponsorship of other government agencies.

Voluntary Product Standards-Developed under procedures published by the Department of Commerce in Part 10, Title 15, of the Code of Federal Regulations. The purpose of the standards is to establish nationally recognized requirements for products, and to provide all concerned interests with a basis for common understanding of the characteristics of the products. NBS administers this program as a supplement to the activities of the private sector standardizing organizations.

Consumer Information Series-Practical information, based on NBS research and experience, covering areas of interest to the consumer. Easily understandable language and illustrations provide useful background knowledge for shopping in today's technological marketplace.

Order above NBS publications from: Superintendent of Documents, Government Printing Office, Washington, D.C. 20402 .

Order following NBS publications-NBSIR's and FIPS from the National Technical Information Services, Springfield, Va. 22161.

Federal Information Processing Standards Publications (FIPS PUBS)-Publications in this series collectively constitute the Federal Information Processing Standards Register. Register serves as the official source of information in the Federal Government regarding standards issued by NBS pursuant to the Federal Property and Administrative Services Act of 1949 as amended, Public Law 89-306 (79 Stat. 1127), and as implemented by Executive Order 11717 (38 FR 12315, dated May 11, 1973) and Part 6 of Title 15 CFR (Code of Federal Regulations).

NBS Interagency Reporis (NBSIR)-A special series of interim or final reports on work performed by NBS for outside sponsors (both government and non-government). In general, initial distribution is handled by the sponsor; public distribution is by the National Technical Information Services (Springfield, Va, 22161) in paper copy or microfiche form.

\section{BIBLIOGRAPHIC SUBSCRIPTION SERVICES}

The following current-awareness and literature-survey bibliographies are issued periodically by the Bureau:

Cryogenic Data Center Current Awareness Service. A literature survey issued biweekly. Annual subscription: Domestic, $\$ 20.00$; Foreign, $\$ 25.00$.

Liquified Natural Gas. A literature survey issued quarterly. Annual subscription: $\$ 20.00$.
Superconducting Devices and Materials. A literature survey issued quarterly. Annual subscription: $\$ 20.00$. Send subscription orders and remittances for the preceding bibliographic services to National Bureau of Standards, Cryogenic Data Center (275.02) Boulder, Colorado 80302 . 
U.S. DEPARTMENT OF COMMERCE

National Bureau of Standards

Washington, D.C. 20234

OFFICIAL BUSINESS

Penalty for Private Use, $\$ 300$
POSTAGE AND FEES PAID U.S. DEPARTMENT OF COMMERCE COM-2 15

SPECIAL FOURTH-CLASS RATE

BOOK

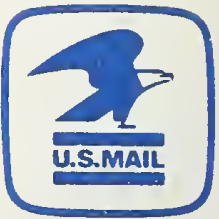

